\title{
Validation of Numerical Models of the Offshore Wind Turbine from the Alpha Ventus Wind Farm against Full-Scale Measurements within OC5 Phase III
}

Popko, Wojciech; Robertson, Amy; Jonkman, Jason; Wendt, Fabian; Thomas, Philipp; Müller, Kolja; Kretschmer, Matthias; Hagen, Torbjørn Ruud; Galinos, Christos; Le Dreff, Jean Baptiste Total number of authors:

27

Published in:

Journal of Offshore Mechanics and Arctic Engineering

Link to article, DOI:

$10.1115 / 1.4047378$

Publication date:

2021

Document Version

Publisher's PDF, also known as Version of record

Link back to DTU Orbit

Citation $(A P A)$ :

Popko, W., Robertson, A., Jonkman, J., Wendt, F., Thomas, P., Müller, K., Kretschmer, M., Hagen, T. R., Galinos, C., Le Dreff, J. B., Gilbert, P., Auriac, B., Oh, S., Qvist, J., Sørum, S. H., Suja-Thauvin, L., Shin, H., Molins, C., Trubat, P., ... Harries, R. (2021). Validation of Numerical Models of the Offshore Wind Turbine from the Alpha Ventus Wind Farm against Full-Scale Measurements within OC5 Phase III. Journal of Offshore Mechanics and Arctic Engineering, 143, [012002]. https://doi.org/10.1115/1.4047378

\section{General rights}

Copyright and moral rights for the publications made accessible in the public portal are retained by the authors and/or other copyright owners and it is a condition of accessing publications that users recognise and abide by the legal requirements associated with these rights.

- Users may download and print one copy of any publication from the public portal for the purpose of private study or research.

- You may not further distribute the material or use it for any profit-making activity or commercial gain

- You may freely distribute the URL identifying the publication in the public portal 
Wojciech Popko

Fraunhofer IWES,

Fraunhofer Institute for Wind Energy Systems, Division Wind Turbine and System Technology, Am Luneort 100,

Bremerhaven 27572, Germany e-mail: wojciech.popko@iwes.fraunhofer.de

Amy Robertson

National Renewable Energy Laboratory, 15013 Denver West Parkway, Golden, C0 80401

e-mail: amy.robertson@nrel.gov

Jason Jonkman

National Renewable Energy Laboratory,

15013 Denver West Parkway, Golden, C0 80401

e-mail: Jason.Jonkman@nrel.gov

Fabian Wendt

National Renewable Energy Laboratory,

15013 Denver West Parkway, Golden, C0 80401

e-mail: fabian.wendt@ramboll.com

Philipp Thomas

Fraunhofer IWES,

Fraunhofer Institute for Wind Energy Systems, Division Wind Turbine and System Technology,

Am Luneort 100,

Bremerhaven 27572, Germany e-mail: philipp.thomas@iwes.fraunhofer.de

Kolja Müller

University of Stuttgart,

Allmandring $5 b$,

Stuttgart Wind Energy,

Stuttgart 70569, Germany

e-mail: kolja.mueller@ge.com

\section{Matthias Kretschmer}

University of Stuttgart, Allmandring 5b,

Stuttgart Wind Energy,

Stuttgart 70569, Germany e-mail: kretschmer@|FB.Uni-Stuttgart.de

\section{Torbjørn Ruud Hagen \\ OWEC Tower AS, \\ Sommerrogata 17 , \\ Oslo 0255, Norway \\ e-mail: Torbjorn.Hagen@owectower.no}

Christos Galinos

Technical University of Denmark,

Department of Wind Energy,

Frederiksborgvej 399,

Roskilde 4000, Denmark e-mail: cgal@dtu.dk

\section{Validation of Numerical Models of the Offshore Wind Turbine From the Alpha Ventus Wind Farm Against Full-Scale Measurements Within OC5 Phase III}

The main objective of the Offshore Code Comparison Collaboration Continuation, with Correlation (OC5) project is validation of aero-hydro-servo-elastic simulation tools for offshore wind turbines (OWTs) through comparison of simulated results to the response data of physical systems. Phase III of the OC5 project validates OWT models against the measurements recorded on a Senvion 5M wind turbine supported by the OWEC Quattropod from the alpha ventus offshore wind farm. The following operating conditions of the wind turbine were chosen for the validation: (1) idling below the cut-in wind speed, (2) rotor-nacelle assembly (RNA) rotation maneuver below the cut-in wind speed, (3) power production below and above the rated wind speed, and (4) shutdown. A number of validation load cases were defined based on these operating conditions. The following measurements were used for validation: (1) strains and accelerations recorded on the support structure and (2) pitch, yaw, and azimuth angles, generator speed, and electrical power recorded from the RNA. Strains were not directly available from the majority of the OWT simulation tools; therefore, strains were calculated based on out-of-plane bending moments, axial forces, and cross-sectional properties of the structural members. The simulation results and measurements were compared in terms of time series, discrete Fourier transforms, power spectral densities, and probability density functions of strains and accelerometers. A good match was achieved between the measurements and models setup by OC5 Phase III participants. [DOI: 10.1115/1.4047378]

Keywords: computational mechanics and design, design of offshore structures, dynamics of structures, ocean energy technology, structural mechanics and foundation, system integrity assessment

Contributed by the Ocean, Offshore, and Arctic Engineering Division of ASME for publication in the Journal of OfFshore Mechanics and Arctic Engineering. Manuscript received December 4, 2019; final manuscript received May 8, 2020; published online July 1, 2020. Assoc. Editor: Madjid Karimirad. 
Jean-Baptiste Le Dreff

Electricitéde France,

Recherche et Développement,

13 Boulevard Gaspard Monge,

Palaiseau 91120, France

e-mail: jean-baptiste.le-dreff@edf.fr

Philippe Gilbert

IFP Energies Nouvelles,

1 et 4 avenue de Bois-Préau,

92852 Rueil-Malmaison Cedex, France

e-mail: philippe.gilbert@ifpen.fr

\section{Bertrand Auriac}

Principia

La Ciotat, 215 Voie Ariane,

La Ciotat 13600, France

e-mail: bertrand.auriac@principia.fr

Sho Oh

Nippon Kaiji Kyokai (ClassNK),

4-7 Kioicho, Chiyoda-Ku,

Tokyo 102-8567, Japan

e-mail: s-oh@classnk.or.jp

Jacob Qvist

4Subsea,

Hagaløkkveien 26, 1383 Asker,

Hvalstad, Norway

e-mail: jacob.qvist@4subsea.com

Stian Høegh Sørum

Norwegian University of Science and Technology,

Department of Marine Technology,

Trondheim 7491, Norway

e-mail: stian.h.sorum@ntnu.no

\section{Loup Suja-Thauvin}

Simis AS, Leonardveien 3 ,

Malm 7790, Norway

e-mail: loup.suja@simis.io

\section{Hyunkyoung Shin}

University of Ulsan, School of Naval Architecture and Ocean

Engineering,

Ulsan, South Korea

e-mail: hkshin@ulsan.ac.kr

Climent Molins

Polytechnic University of Catalonia, Campus Nord, Carrer de Jordi Girona, 1, 3, Barcelona 08034, Spain e-mail: climent.molins@upc.edu

Pau Trubat

Polytechnic University of Catalonia, Campus Nord, Carrer de Jordi Girona, 1, 3,

Barcelona 08034, Spain

e-mail: pau.trubat.casal@upc.edu

Paul Bonnet

Siemens Industry Software, Luis, Carrer Lluís Muntadas, NNo. 5,

Cornellà de Llobregat,

Barcelona 08940, Spain

e-mail: paul.bonnet@siemens.com 


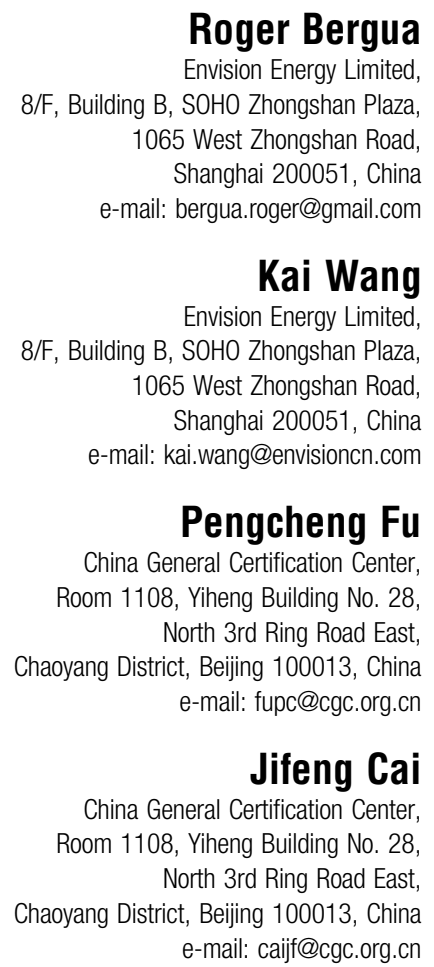

Kai Wang

Envision Energy Limited, 8/F, Building B, SOHO Zhongshan Plaza, 1065 West Zhongshan Road, Shanghai 200051, China e-mail: kai.wang@envisioncn.com

Pengcheng Fu

China General Certification Center, Room 1108, Yiheng Building No. 28, North 3rd Ring Road East, Chaoyang District, Beijing 100013, China e-mail: fupc@cgc.org.cn

Jifeng Cai

China General Certification Center, Room 1108, Yiheng Building No. 28, North 3rd Ring Road East, Chaoyang District, Beijing 100013, China e-mail: caijf@cgc.org.cn

Zhisong Cai

China General Certification Center, Room 1108, Yiheng Building No. 28, North 3rd Ring Road East, Chaoyang District, Beijing 100013, China e-mail: caizs@cgc.org.cn

\section{Armando Alexandre} DNV GL,

One Linear Park, Avon Street, Temple Quay, Bristol BS2 OPS, UK e-mail: armando.alexandre@gmail.com

\section{Robert Harries}

DNV GL,

Edificio Trovador,

Plaza de Antonio Beltrán Martínez, Zaragoza 50002, Spain e-mail: robert.harries@dnvgl.com

\section{Introduction}

The Offshore Code Comparison Collaboration Continuation, with Correlation (OC5) project [1], which operates under the International Energy Agency (IEA) Wind Task 30 is the follow-up project of OC3 and OC4, which ran from 2005 to 2009 and from 2010 to 2014, respectively. The focus of OC3 and OC4 was to verify and benchmark simulation tools for offshore wind turbines (OWTs) with an emphasis on support structures through code-to-code comparison. This verification work led to improvements in model accuracy, which is a crucial achievement because the advancement of the offshore wind industry is closely tied to the development and accuracy of aero-servo-hydro-elastic OWT models [2,3]. Participants of OC 3 and OC4 expressed great interest in creating an extension to IEA Task 30 to focus on validating offshore wind modeling tools against experimental and in situ data.

The OC5 project was focused on validation of aero-hydro-servoelastic simulation tools for OWTs through comparison of simulated results to the response data of physical systems. OC5 was organized in three phases jointly coordinated by the National Renewable Energy Laboratory (NREL) from the United States and the Fraunhofer Institute for Wind Energy Systems IWES (IWES) from Germany. While the first two phases dealt with physical response data from tank tests [4,5], Phase III dealt with the full-scale open-ocean system. Phase III of the OC5 project analyzed the Senvion 5M wind turbine supported by the OWEC Quattropod from the alpha ventus offshore wind farm. The reference met-ocean and structural measurements were provided by the Research at Alpha VEntus (RAVE) consortium for model validation. Alpha ventus is located in the North Sea at the site of the average water depth of $28 \mathrm{~m}$, around $45 \mathrm{~km}$ north of the Borkum island, as shown in Fig. 1.

The validation results discussed in this paper represent the outcome of several modeling iterations. Within each modeling iteration, the participants updated their simulation settings to better match the measurements. It should be noted that prior to the 
(a)

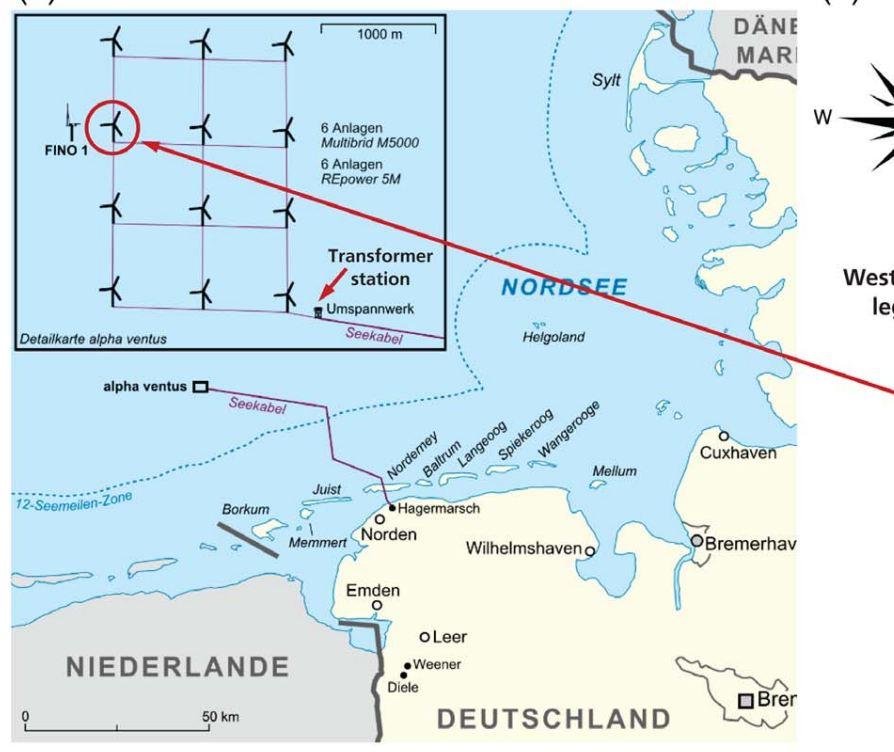

(b)

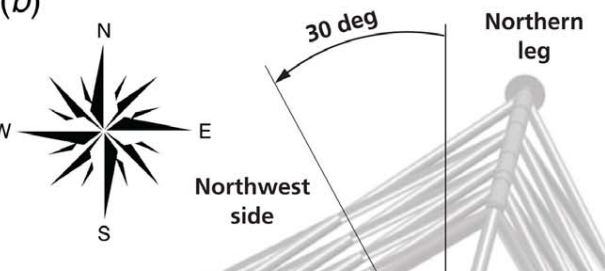

Northeast side

eg

Fig. 1 (a) Location of the OWT within the alpha ventus wind farm-modified sketch from Ref. [6] and (b) jacket orientation with regard to true north-view from the top

validation, all numerical OWT models were verified to fix modeling errors. Their verification was published in a separate paper by Popko et al. [7]. The models were not calibrated to the data after the verification step.

A number of academic and industrial project partners from 11 countries participated in the task. Those actively involved in Phase III are listed in Table 1.

A set of state-of-the-art simulation tools for OWT modeling is represented in Phase III of the OC5 project. Table 2 summarizes some of their simulation capabilities that are important for validation of OWT models in Phase III.

\section{Definition of Offshore Wind Turbine Model}

A description of the numerical model of the OWT consisting of the rotor-nacelle assembly (RNA), the tower, the transition piece (TP), the jacket substructure (OWEC Quattropod), its foundation piles, and soil properties was setup at Fraunhofer IWES by Popko [8] based on the data provided by Senvion and OWEC tower.
The complexity of the OWT models was proven adequate for this validation task [7]. On the other hand, the models were relatively simple (load-analysis level) to minimize the implementation effort and modeling errors in the simulation tools.

The verification (code-to-code comparison) and tuning of these models, prior to their validation, was performed against a reference OWT model implemented in Flex5-Poseidon by the University of Stuttgart-Stuttgart Wind Energy (SWE) and documentation provided by Senvion and OWEC Tower. The reference OWT model from SWE contains structural and aerodynamic properties of the real blades and the fully functional controller (torque, pitch, yaw, etc.) that could not be disclosed to the OC5 Phase III participants. The SWE reference model was extensively validated by Kaufer and Cheng [9] and Müller et al. [10] within the RAVE projectsOffshore-Windenergieanlagen (OWEA) and OWEA Loads [11], respectively; therefore, it was also considered as a reference model for the verification of other numerical models prior to their validation in Phase III. The verification results of the models, which are used in the validation exercise presented in this paper, were published in a separate paper by Popko et al. [7].

Table 1 Participants of OC5 Phase III and their tools

\begin{tabular}{|c|c|c|c|}
\hline Organization full name & Abbreviation & Country & Tool \\
\hline 4Subsea, Simis AS & 4S-Simis & Norway & ASHES \\
\hline China General Certification Center & CGC & China & Bladed V4.8 \\
\hline Nippon Kaiji Kyokai & ClassNK & Japan & NK-UTWind \\
\hline Technical University of Denmark - Department of Wind Energy & DTU & Denmark & HAWC2 \\
\hline DNV GL & DNVGL & UK & Bladed V4.8 \\
\hline Electricité de France - Recherche et Développement & EDFRD & France & FAST V8, DIEGO \\
\hline Envision Energy Limited & Envision & China & SAMCEF Wind Turbines 18.0 (SWT) \\
\hline IFP Energies Nouvelles, PRINCIPIA & IFPEN-PR & France & DeepLinesWind V5R4 \\
\hline Fraunhofer IWES - Division Wind Turbine and System Technology & IWES & Germany & MoWiT \\
\hline National Renewable Energy Laboratory & NREL & USA & OpenFAST v0.1.0 \\
\hline $\begin{array}{l}\text { Norwegian University of Science and Technology - Department of Marine } \\
\text { Technology }\end{array}$ & NTNU & Norway & SIMA \\
\hline OWEC Tower & OWEC & Norway & - \\
\hline Senvion & Senvion & Germany & - \\
\hline Siemens Industry Software & SIS & Spain & SAMCEF Wind Turbines 18.0 (SWT) \\
\hline University of Stuttgart - Stuttgart Wind Energy & SWE & Germany & Simpack \\
\hline $\begin{array}{l}\text { University of Ulsan - School of Naval Architecture and Ocean } \\
\text { Engineering }\end{array}$ & UOU & $\begin{array}{l}\text { The Republic of } \\
\text { Korea }\end{array}$ & FAST V8 \\
\hline Polytechnic University of Catalonia & UPC & Spain & FloaWDyn \\
\hline
\end{tabular}


Table 2 Overview of simulation capabilities of tools used within OC5 Phase III

\begin{tabular}{|c|c|c|c|c|}
\hline Tool & Structural & Aerodynamics & Hydrodynamics & Control \\
\hline \multirow[t]{4}{*}{ ASHES } & Structural dynamics: FEM & $\begin{array}{l}\text { Basic aerodynamics: BEM + Glauert correction } \\
\text { + Prandtl tip and root losses + skew inflow } \\
\text { correction }\end{array}$ & $\begin{array}{l}\text { Regular wave model: } \\
\text { Airy }{ }^{\text {str }}\end{array}$ & DLL, UD \\
\hline & Beam model: Euler-Bernoulli & Dynamic wake model: $\varnothing$ ye & $\begin{array}{l}\text { Irregular wave model: } \\
\text { JONSWAP/PM }\end{array}$ & \\
\hline & $\begin{array}{l}\text { Damping model: Stiffness } \\
\text { proportional Rayleigh }\end{array}$ & Dynamic stall model: Øye & & \\
\hline & $\begin{array}{l}\text { Wind field grid format: } \\
\text { Rectangular }\end{array}$ & Hydro model: ME & & \\
\hline \multirow[t]{3}{*}{ Bladed V4.8 } & $\begin{array}{l}\text { Structural dynamics: MBS }+ \\
\text { flexible modally reduced bodies }\end{array}$ & $\begin{array}{l}\text { Basic aerodynamics: BEM + Glauert correction } \\
\text { + Prandtl tip and root losses + skew inflow } \\
\text { correction }\end{array}$ & $\begin{array}{l}\text { Regular wave model: } \\
\text { Airy }{ }^{\text {str }} \text {, Stream }\end{array}$ & DLL, UD \\
\hline & Beam model: Timoshenko & Dynamic wake model: Øye or Pitt and Peters & $\begin{array}{l}\text { Irregular wave model: } \\
\text { JONSWAP/PM }\end{array}$ & \\
\hline & Damping model: Modal & $\begin{array}{l}\text { Dynamic stall model: Beddoes-Leishman or Øye } \\
\text { Wind field grid format: Rectangular }\end{array}$ & Hydro model: $\mathrm{ME}+\mathrm{MF}$ & \\
\hline \multirow[t]{3}{*}{$\begin{array}{l}\text { DeepLinesWind } \\
\text { V5R4 (DeepLW) }\end{array}$} & Structural dynamics: FEM & $\begin{array}{l}\text { Basic aerodynamics: BEM + Glauert correction } \\
\text { + Prandtl tip and root losses + skew inflow } \\
\text { correction + relaxation of induction factors }\end{array}$ & $\begin{array}{l}\text { Regular wave model: } \\
\text { Airy }^{\text {tr }}, \text { Stream }\end{array}$ & DLL, UD \\
\hline & Beam model: Mindlin-Reissner & Dynamic wake model: $\varnothing$ ye & $\begin{array}{l}\text { Irregular wave model: } \\
\text { JONSWAP/PM }\end{array}$ & \\
\hline & $\begin{array}{l}\text { Damping model: Stiffness } \\
\text { proportional Rayleigh } \\
\text { Wind field grid format: } \\
\text { Rectangular }\end{array}$ & Dynamic stall model: Øye or Ris $\emptyset$ & Hydro model: ME & \\
\hline \multirow[t]{3}{*}{ DIEGO } & $\begin{array}{l}\text { Structural dynamics: FEM } \\
\text { Beam model: Euler-Bernoulli }\end{array}$ & $\begin{array}{l}\text { Basic aerodynamics: BEM + Glauert correction } \\
\text { + Prandtl tip and root losses } \\
\text { Dynamic wake model: Pitt and Peters }\end{array}$ & $\begin{array}{l}\text { Regular wave model: } \\
\text { Airy }^{\text {str }} \text {, Stokes } \\
\text { Irregular wave model: } \\
\text { JONSWAP/PM }\end{array}$ & DLL \\
\hline & $\begin{array}{l}\text { Damping model: Stiffness and mass } \\
\text { proportional Rayleigh }\end{array}$ & Dynamic stall model: Beddoes-Leishman or Ris $\emptyset$ & Hydro model: $\mathrm{ME}+\mathrm{MF}$ & \\
\hline & & Wind field grid format: Rectangular & & \\
\hline \multirow{4}{*}{$\begin{array}{l}\text { FAST V8/ } \\
\text { OpenFAST v0.1.0 }\end{array}$} & Structural dynamics: Substructure: & Basic aerodynamics: $\mathrm{BEM}+$ Glauert correction & Regular wave model: & DLL, UD \\
\hline & $\begin{array}{l}\text { FEM + Craig-Bampton; Turbine: } \\
\text { FEM preprocessor + Modal/MBS; } \\
\text { Blades: Modal }\end{array}$ & + Prandtl tip and root losses & Airy ${ }^{\text {str }}$, Stokes 2 nd order & \\
\hline & $\begin{array}{l}\text { Beam model: Substructure and } \\
\text { blades: Timoshenko; Turbine: } \\
\text { Euler-Bernoulli }\end{array}$ & Dynamic wake model: Pitt and Peters & $\begin{array}{l}\text { Irregular wave model: } \\
\text { JONSWAP/PM }\end{array}$ & \\
\hline & Damping model: Modal & $\begin{array}{l}\text { Dynamic stall model: Beddoes-Leishman } \\
\text { Wind field grid format: Rectangular }\end{array}$ & Hydro models: ME & \\
\hline \multirow[t]{3}{*}{ FloaWDyn } & $\begin{array}{l}\text { Structural dynamics: FEM } \\
\text { (co-rotational formulation) } \\
\text { Beam model: Euler-Bernoulli }\end{array}$ & $\begin{array}{l}\text { Basic aerodynamics: BEM (AeroDyn)+ Glauert } \\
\text { correction + Prandtl tip and root losses } \\
\text { Dynamic wake model: Peters-He dynamic inflow }\end{array}$ & $\begin{array}{l}\text { Regular wave model: } \\
\text { Airy }{ }^{\text {str }} \text {, Stokes fifth order } \\
\text { Irregular wave model: } \\
\text { JONSWAP/PM }\end{array}$ & DLL, UD \\
\hline & $\begin{array}{l}\text { Damping model: Support structure: } \\
\text { stiffness and mass proportional } \\
\text { Rayleigh }\end{array}$ & Dynamic stall model: Beddoes-Leishman & Hydro model: ME & \\
\hline & & $\begin{array}{l}\text { Wind field grid format: Single point wind at hub } \\
\text { height }\end{array}$ & & \\
\hline \multirow[t]{4}{*}{ HAWC2 } & Structural dynamics: MBS/FEM & $\begin{array}{l}\text { Basic aerodynamics: BEM with Madsen and } \\
\text { Larsen correction for shear and dynamic inflow, } \\
\text { Glauert and Coleman modification for skewed } \\
\text { inflow }\end{array}$ & $\begin{array}{l}\text { Regular wave model: } \\
\text { Airy }\end{array}$ & DLL \\
\hline & Beam model: Timoshenko & Dynamic wake model: Øye & $\begin{array}{l}\text { Irregular wave model: } \\
\text { JONSWAP/PM }\end{array}$ & \\
\hline & $\begin{array}{l}\text { Damping model: Support structure } \\
\text { and blades: stiffness proportional } \\
\text { Rayleigh }\end{array}$ & Dynamic stall model: Øye or Beddoes-Leishman & Hydro model: ME & \\
\hline & & Wind field grid format: Rectangular & & \\
\hline \multirow[t]{4}{*}{ NK-UTWind } & Structural dynamics: FEM & Basic aerodynamics: BEM (AeroDyn v14) & $\begin{array}{l}\text { Regular wave model: } \\
\text { Airy }\end{array}$ & DLL \\
\hline & Beam model: Euler-Bernoulli & Dynamic wake model: Pitt and Peters & $\begin{array}{l}\text { Irregular wave model: } \\
\text { JONSWAP/PM }\end{array}$ & \\
\hline & $\begin{array}{l}\text { Damping model: Support structure: } \\
\text { stiffness proportional Rayleigh; } \\
\text { Blades: modal }\end{array}$ & Dynamic stall model: Beddoes-Leishman & Hydro model: ME & \\
\hline & & Wind field grid format: Rectangular & & \\
\hline
\end{tabular}


Table 2 Continued

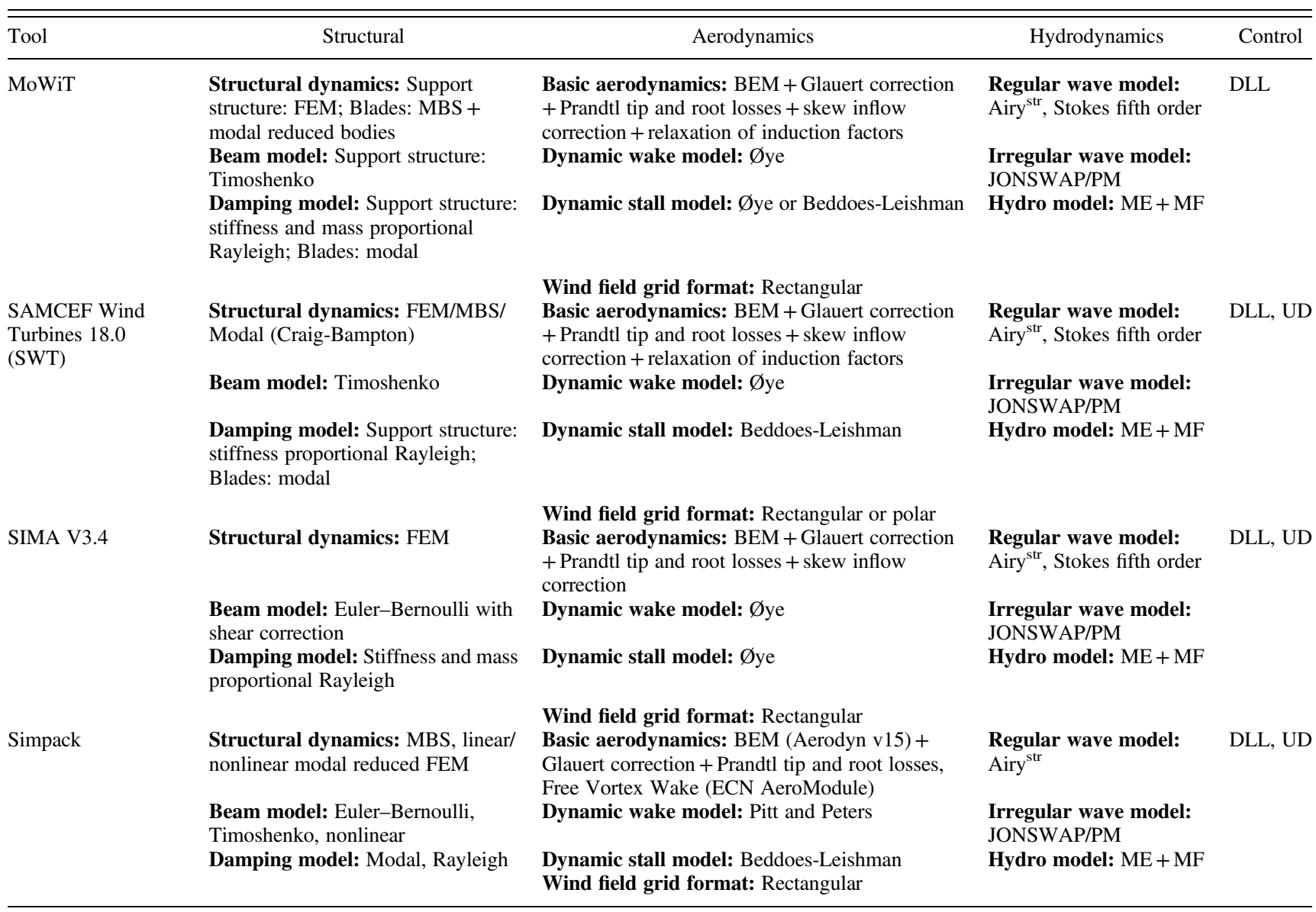

Note: Airy ${ }^{\text {str }}$ linear Airy wave theory with Wheeler stretching; JONSWAP: deep-water wave spectrum; Stokes: nonlinear Stokes wave theory; BEM: blade element momentum; ME: semi-empirical Morison's equation; Stream: Dean's Stream function wave theory; DLL: dynamic-link library; MF: MacCamy-Fuchs linear diffraction theory; UD: user-defined subroutine; FEM: finite element method; and PM: Pierson-Moskowitz spectrum.

\section{Alpha Ventus Measurements for Validation}

The reference measurements at different operating conditions were selected by SWE considering the following constraints: (1) Met-ocean conditions and the structural measurements had to be available for the same time window; (2) data from the majority of the strain gauges and accelerometers, which are located at the critical positions for capturing the global system response, should be available; (3) the wind turbine should experience free-flow conditions-no wake effect from other wind turbines in the wind farm; and (4) measurements should be 10-min long and leave sufficient time in between the adjacent measurements.

The measurement time period between April 2011 and January 2012 was used for screening because during that time the majority of sensors operated correctly. The above-baseline filtration constraints were applied to identify data regions that met the following conditions:

(1) Idling below the cut-in wind speed.

(2) Idling below the cut-in wind speed and the RNA rotation maneuver.

(3) Power production below the rated wind speed.

(4) Power production above the rated wind speed.

(5) Power production above the rated wind speed, followed by the normal shut-down.

The following 10-min structural measurements, sampled with $50 \mathrm{~Hz}$, were available for validation purposes:

(1) Blade pitch angle and azimuth position, expressed in deg.

(2) Yaw position with regard to true north, expressed in deg.

(3) Generator speed, expressed in rpm.

(4) Electrical power, expressed in $\mathrm{kW}$.
(5) Accelerations at the tower top and bottom, expressed in $\mathrm{m} / \mathrm{s}^{2}$.

(6) Bending moments at the tower bottom, expressed in $\mathrm{kNm}$.

(7) Uncalibrated strains at different positions along the jacket substructure, expressed in $\mu \mathrm{m} / \mathrm{m}$.

The location of the strain gauges along the jacket substructure is shown in Fig. 2. There are four sensors for each measurement location. They are positioned around the circumferences of the legs and braces. Each sensor is effectively one strain gauge composed of four resistances creating a full-bridge configuration. The full-bridge configuration helps to increase the output signal and optimizes compensation of temperature and mechanical noise impacts. For validation purposes, a single strain gauge is selected from a given location.

It should be noted that all strain gauges were installed and calibrated in the dry dock, before the jacket was transported and installed offshore. Many of the installed sensors broke after the first year of the wind turbine operation. In addition, a signal drift was observed in many of the operating sensors. It was also discovered that some of the measured signal had flipped signs. A calibration of the sensors was done to the best knowledge of the authors. However, some uncertainty in the measurements cannot be removed. Only systematic errors in the measurements were removed.

The following met-ocean conditions were available in terms of their statistics (mean, minimum, maximum, and standard deviation values):

(1) Wind speed at the hub height, expressed in $\mathrm{m} / \mathrm{s}$.

(2) Wind direction with regard to true north, expressed in deg.

(3) Significant wave height, expressed in $\mathrm{m}$.

(4) Peak-spectral wave period, expressed in s.

(5) Wave direction with regard to true north, expressed in deg. 


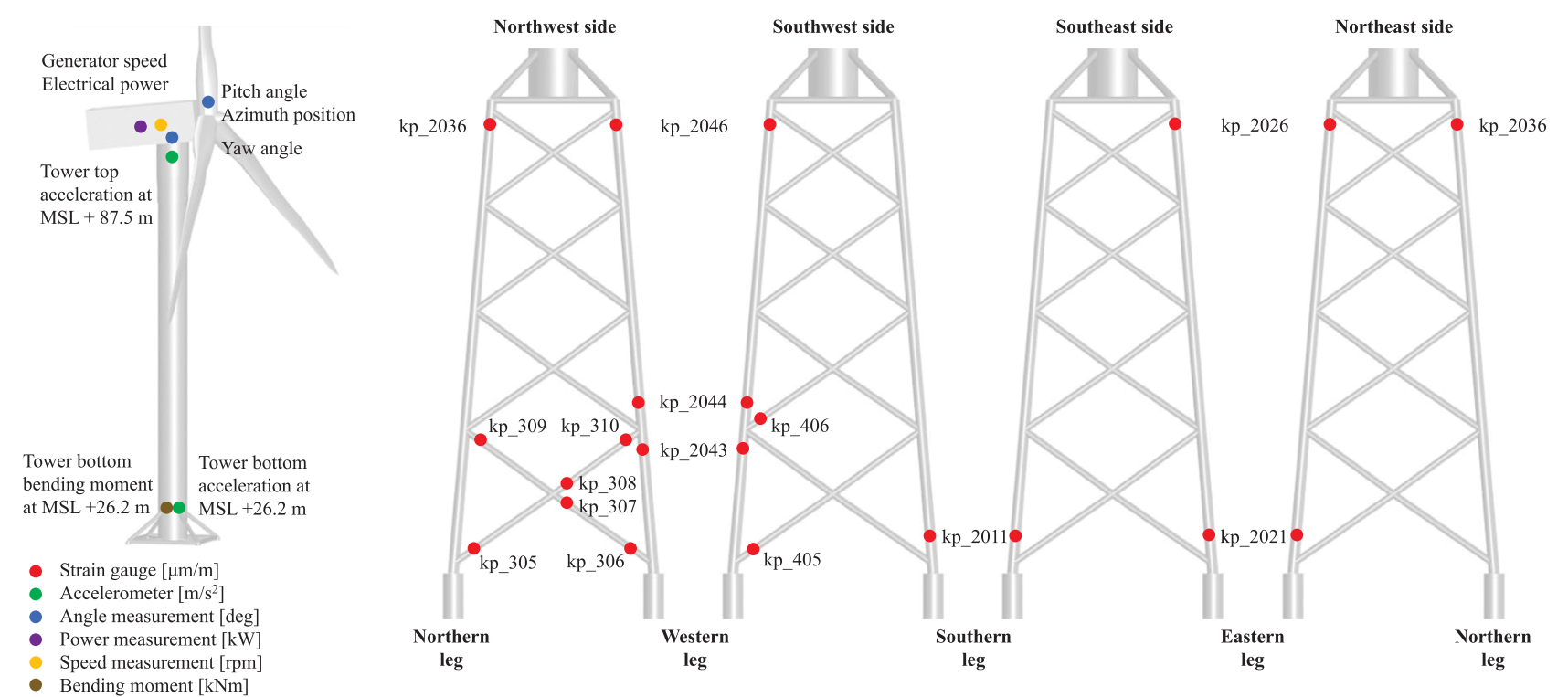

Fig. 2 Placement of sensors along RNA, tower, and jacket substructure, which were available for OC5 Phase III

The met-ocean conditions were not measured directly at the location of the OWT. The wind data were recorded at the FINO I platform, and the wave data were recorded nearby the transformer station located in the southeast corner of the alpha ventus wind farm (see Fig. 1). The wind data were available in terms of 10-min statistics, whereas the wave data were provided as a 3-h statistic.

Other Data Not Directly Available From Measurements. Some data were not directly available from the RAVE measurements or were difficult to derive. Therefore, it was necessary to assume their values based on the available standards or engineering practice of project participants:

(1) Inclination of the mean wind flow with regard to a horizontal plane according to IEC 61400-3 [12].

(2) The vertical and lateral turbulence intensities (TI) are calculated as 0.8 and 0.5 of the measured horizontal TI value.

(3) Air density according to IEC 61400-3 [12].

(4) Seawater density according to IEC 61400-3 [12].
(5) Marine growth vertical range, thickness, and density according to the assumptions from the OWEC Tower documentation. It should be emphasized that the measurements concerning the distribution of the marine growth along the height of the jacket structure were not available. There are also no data concerning the marine growth thickness distribution.

(6) Drag and inertia coefficients for jacket members covered with marine growth were derived from the SWE reference model implemented in Flex5-Poseidon.

\section{Validation Methodology}

The postprocessing of all simulation results was performed internally at Fraunhofer IWES. The simulation results were compared against the measurements in terms of time series, discrete Fourier transforms (DFTs), power spectral densities (PSDs), and probability density functions (PDFs). Note that the DFT shows the amplitude

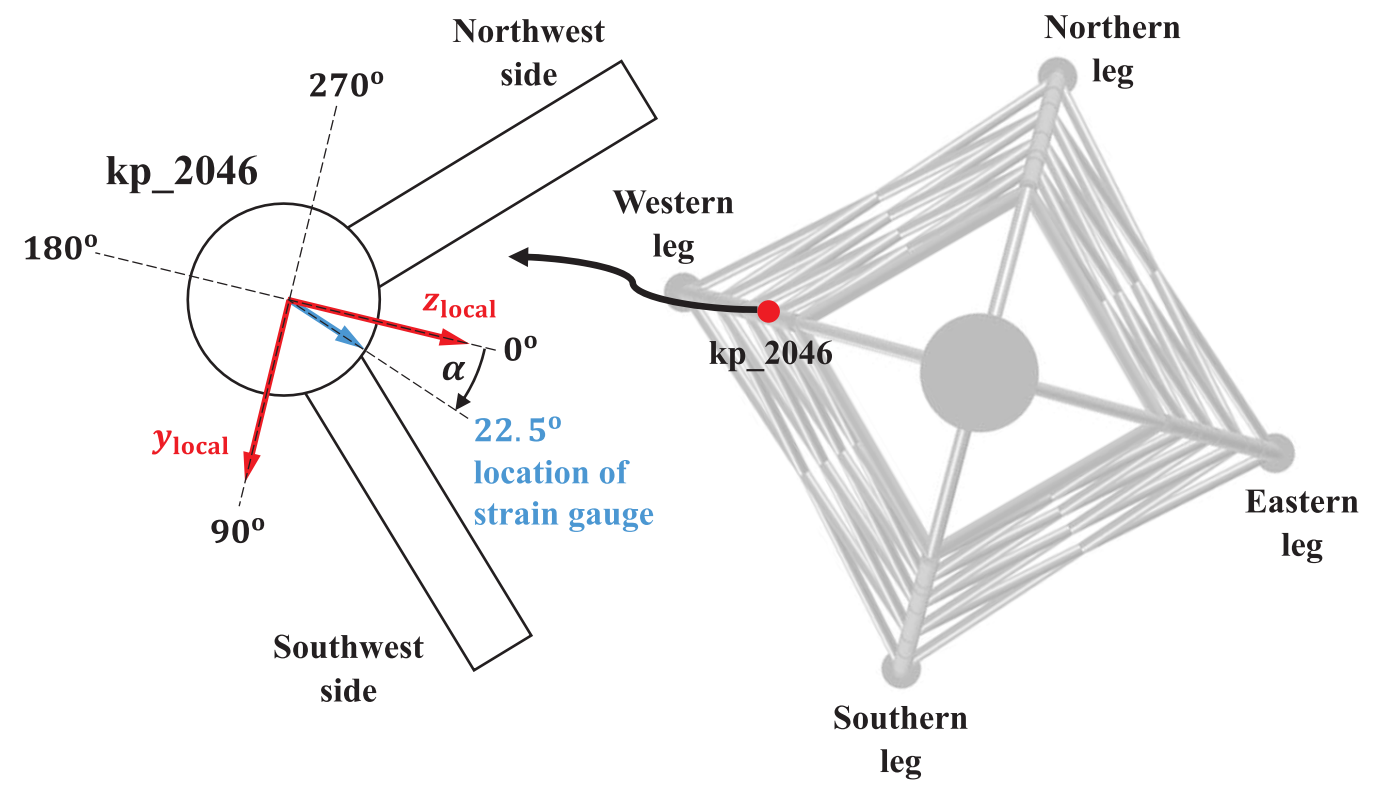

Fig. 3 Member local coordinate system at node kp_2046 (indicated with "local" subscript), location of the strain gauge indicated with $\alpha$ angle 


\begin{tabular}{|c|c|c|c|c|}
\hline Load Case & OWT settings & Wind conditions & Marine conditions & $\begin{array}{l}\text { Simulation } \\
\text { settings }\end{array}$ \\
\hline 1.0 - Idling below cut-in wind speed & $\begin{array}{l}\text { - Free idling, rotor brake disabled } \\
\text { - } \phi_{\mathrm{b}}=0 \mathrm{deg} \\
\text { - } \theta_{\mathrm{p}}=90 \mathrm{deg} \\
\text { - } \theta_{\text {yaw }}=26.8 \mathrm{deg}\end{array}$ & $\begin{array}{l}\text { - Steady, deterministic wind } \\
\text { - } V_{\text {hub }}=3.61 \mathrm{~m} / \mathrm{s} \\
\text { - } \theta_{\text {wind }}=270 \mathrm{deg} \\
\text { - } \alpha=0.14\end{array}$ & $\begin{array}{l}\text { - Still water } \\
\text { - } T_{\text {sim }}=100 \mathrm{~s} \\
\text { - } \Delta t=0.05 \mathrm{~s}\end{array}$ & $\begin{array}{l}\text { - } T_{\text {pre }}=\text { user } \\
\text { defined }\end{array}$ \\
\hline $\begin{array}{l}1.1 \mathrm{x} \text { - Idling below cut-in wind } \\
\text { speed }\end{array}$ & $\begin{array}{l}\text { - Free idling, rotor brake disabled } \\
\text { - } \phi_{\mathrm{b}}=0 \mathrm{deg} \\
\text { - } \theta_{\mathrm{p}}=90 \mathrm{deg} \\
\text { - } \theta_{\text {yaw }}=26.8 \mathrm{deg}\end{array}$ & $\begin{array}{l}\text { - Steady, deterministic wind } \\
\text { - } V_{\text {hub }}=3.61 \mathrm{~m} / \mathrm{s} \\
\text { - } \theta_{\text {wind }}=270 \mathrm{deg} \\
\text { - } \alpha=0.14\end{array}$ & $\begin{array}{l}\text { - Irregular Airy with PM, } 6 \\
\text { seeds } \\
\text { - } H_{\mathrm{s}}=0.89 \mathrm{~m} \\
\text { - } T_{\mathrm{p}}=9.88 \mathrm{~s} \\
\text { - } \theta_{\text {wave }}=345.8 \mathrm{deg}\end{array}$ & $\begin{array}{l}\text { - } T_{\text {pre }}=\text { user } \\
\quad \text { defined } \\
\text { - } T_{\text {sim }}=600 \mathrm{~s} \\
\text { - } \Delta t=0.05 \mathrm{~s}\end{array}$ \\
\hline \multirow{2}{*}{$\begin{array}{l}1.2 \text { - Idling below cut-in wind speed, } \\
\text { RNA rotation in counterclockwise } \\
\text { direction }\end{array}$} & - Free idling, rotor brake disabled & - Steady, deterministic wind & - Regular Airy wave & $\begin{array}{l}-T_{\text {pre }}=\text { user } \\
\text { defined }\end{array}$ \\
\hline & $\begin{array}{l}-\phi_{\mathrm{b}}=0 \mathrm{deg} \\
-\theta_{\mathrm{p}}=90 \mathrm{deg} \\
-\dot{\theta}_{\text {yaw }}=-0.28 \mathrm{deg} / \mathrm{s} \\
\text { - } \theta_{\text {yaw,init }}=20 \mathrm{deg} \\
\text { - } \theta_{\text {yaw,final }}=58 \mathrm{deg}\end{array}$ & $\begin{array}{l}\text { - } V_{\text {hub }}=3.61 \mathrm{~m} / \mathrm{s} \\
\text { - } \theta_{\text {wind }}=263.6 \mathrm{deg} \\
\text { - } \alpha=0.14\end{array}$ & $\begin{array}{l}\text { - } H=0.57 \mathrm{~m} \\
\text { - } T=10.65 \mathrm{~s} \\
\text { - } \theta_{\text {wave }}=344.6 \mathrm{deg}\end{array}$ & $\begin{array}{l}\text { - } T_{\mathrm{sim}}= \\
\quad 1150 \mathrm{~s} \\
\text { - } \Delta t=0.05 \mathrm{~s}\end{array}$ \\
\hline $\begin{array}{l}2.1 \mathrm{x} \text { - Power production below rated } \\
\text { wind speed }\end{array}$ & $\begin{array}{l}\text { - Power production governed by } \\
\text { external controller } \\
\text { - } \theta_{\mathrm{p}}=0 \mathrm{deg} \\
\text { - } \theta_{\text {yaw }}=267.5 \mathrm{deg}\end{array}$ & $\begin{array}{l}\text { - Stochastic wind field, } \\
\text { Kaimal spectrum model, } 6 \\
\text { seeds } \\
\text { - } V_{\text {hub }}=7.9 \mathrm{~m} / \mathrm{s} \\
\text { - } \sigma_{\text {long }}=0.38 \mathrm{~m} / \mathrm{s} \\
\text { - } \sigma_{\text {lat }}=0.8 \sigma_{\text {long }} \mathrm{m} / \mathrm{s} \\
\text { - } \sigma_{\text {vert }}=0.5 \sigma_{\text {long }} \mathrm{m} / \mathrm{s} \\
\text { - } \theta_{\text {wind }}=255.9 \mathrm{deg} \\
\text { - } \alpha=0.14\end{array}$ & $\begin{array}{l}\text { - Irregular Airy with PM, } 6 \\
\text { seeds } \\
\text { - } H_{\mathrm{s}}=2.55 \mathrm{~m} \\
\text { - } T_{\mathrm{p}}=6.57 \mathrm{~s} \\
\text { - } \theta_{\text {wave }}=330.2 \mathrm{deg}\end{array}$ & $\begin{array}{l}\text { - } T_{\text {pre }}=\text { user } \\
\text { defined } \\
\text { - } T_{\text {sim }}=600 \mathrm{~s} \\
\text { - } \Delta t=0.05 \mathrm{~s}\end{array}$ \\
\hline $\begin{array}{l}2.2 \mathrm{x} \text { - Power production above rated } \\
\text { wind speed }\end{array}$ & $\begin{array}{l}\text { - Power production governed by } \\
\text { external controller } \\
\text { - } \theta_{\text {yaw }}=235.5 \mathrm{deg}\end{array}$ & $\begin{array}{l}\text { - Stochastic wind field, } \\
\text { Kaimal spectrum model, } 6 \\
\text { seeds } \\
\text { - } V_{\text {hub }}=16.57 \mathrm{~m} / \mathrm{s} \\
\text { - } \sigma_{\text {long }}=0.45 \mathrm{~m} / \mathrm{s} \\
\text { - } \sigma_{\text {lat }}=0.8 \sigma_{\text {long }} \mathrm{m} / \mathrm{s} \\
\text { - } \sigma_{\text {vert }}=0.5 \sigma_{\text {long }} \mathrm{m} / \mathrm{s} \\
\text { - } \theta_{\text {wind }}=218.3 \mathrm{deg} \\
\text { - } \alpha=0.28\end{array}$ & $\begin{array}{l}\text { - Irregular Airy with PM, } 6 \\
\text { seeds } \\
\text { - } H_{\mathrm{s}}=1.60 \mathrm{~m} \\
\text { - } T_{\mathrm{p}}=6.26 \mathrm{~s} \\
\text { - } \theta_{\text {wave }}=260.4 \mathrm{deg}\end{array}$ & $\begin{array}{l}\text { - } T_{\text {pre }}=\text { user } \\
\text { defined } \\
\text { - } T_{\text {sim }}=600 \mathrm{~s} \\
\text { - } \Delta t=0.05 \mathrm{~s}\end{array}$ \\
\hline $\begin{array}{l}2.3 \mathrm{x} \text { - Power production above rated } \\
\text { wind speed }\end{array}$ & $\begin{array}{l}\text { - Power production governed by } \\
\text { external controller } \\
\text { - } \theta_{\text {yaw }}=254.3 \mathrm{deg}\end{array}$ & $\begin{array}{l}\text { - Stochastic wind field, } \\
\text { Kaimal spectrum model, } 6 \\
\text { seeds } \\
\text { - } V_{\text {hub }}=18.98 \mathrm{~m} / \mathrm{s} \\
\text { - } \sigma_{\text {long }}=0.34 \mathrm{~m} / \mathrm{s} \\
\text { - } \sigma_{\text {lat }}=0.8 \sigma_{\text {long }} \mathrm{m} / \mathrm{s} \\
\text { - } \sigma_{\text {vert }}=0.5 \sigma_{\text {long }} \mathrm{m} / \mathrm{s} \\
\text { - } \theta_{\text {wind }}=231.6 \mathrm{deg} \\
\text { - } \alpha=0.36\end{array}$ & $\begin{array}{l}\text { - Irregular Airy with PM, } 6 \\
\text { seeds } \\
\text { - } H_{\mathrm{s}}=1.34 \mathrm{~m} \\
\text { - } T_{\mathrm{p}}=5.84 \mathrm{~s} \\
\text { - } \theta_{\text {wave }}=272.7 \mathrm{deg}\end{array}$ & $\begin{array}{l}\text { - } T_{\text {pre }}=\text { user } \\
\text { defined } \\
\text { - } T_{\text {sim }}=600 \mathrm{~s} \\
\text { - } \Delta t=0.05 \mathrm{~s}\end{array}$ \\
\hline $3.1 \mathrm{x}-$ Shutdown & $\begin{array}{l}\text { - Normal shutdown governed by } \\
\text { external controller } \\
\text { - Shutdown triggered at } T_{\text {shut-down }} \\
\text { - Generator torque drops linearly } \\
\text { from the rated value to } 0 \mathrm{Nm} \\
\text { within } 10 \mathrm{~s} \\
\text { - } \dot{\theta}_{\mathrm{p}}=2.54 \mathrm{deg} / \mathrm{s} \\
\text { - } \theta_{\text {yaw }}=268.3 \mathrm{deg}\end{array}$ & $\begin{array}{l}\text { - } \sigma_{\mathrm{long}}=0.56 \mathrm{~m} / \mathrm{s} \\
\text { - } \sigma_{\text {lat }}=0.8 \sigma_{\text {long }} \mathrm{m} / \mathrm{s} \\
\text { - } \sigma_{\text {vert }}=0.5 \sigma_{\text {long }} \mathrm{s} / \mathrm{s} \\
\text { - } \theta_{\text {wind }}=247.4 \mathrm{deg} \\
\text { - } \alpha=0.14\end{array}$ & $\begin{array}{l}\text { - Irregular Airy with PM, } 6 \\
\text { seeds } \bullet T_{\text {pre }}=200 \mathrm{~s} \\
\text { - } H_{\mathrm{s}}=1.51 \mathrm{~m} \\
\text { - } T_{\mathrm{p}}=6.82 \mathrm{~s} \\
\text { - } \theta_{\text {wave }}=284.4 \mathrm{deg}\end{array}$ & $\begin{array}{l}\text { - } T_{\text {shut-down }} \\
=T_{\text {pre }}+ \\
50 \mathrm{~s} \\
\text { - } T_{\text {sim }}=600 \mathrm{~s} \\
\text { - } \Delta t=0.05 \mathrm{~s}\end{array}$ \\
\hline
\end{tabular}

Note: $\theta_{\mathrm{p}}$ : blade pitch angle, $90 \mathrm{deg}$ for blades pitched to feather; $\sigma_{\text {long }}$ standard deviation of longitudinal wind component; $H$ : regular wave height; $\dot{\theta}_{\mathrm{p}}:$ blade pitch rate, positive value toward feather; $\sigma_{\mathrm{lat}}:$ standard deviation of lateral wind component; $H_{\mathrm{s}}$ : significant wave height; $\theta_{\text {yaw }}$ yaw position with regard to true north; $\sigma_{\text {vert }}:$ standard deviation of vertical wind component; $T$ : regular wave period; $\theta_{\text {yaw }}$, init: initial yaw position with regard to true north; $\phi_{\mathrm{b}}$ : blade azimuth angle, 0 deg for first blade pointing upward; $T_{\mathrm{p}}$ : peak-spectral wave period; $\theta_{\text {yaw }}$, final: final yaw position with regard to true north; $\alpha$ : wind shear; $T_{\text {pre: }}$ presimulation time; $\dot{\theta}_{\text {yaw }}$ : yaw rate, negative value for counterclockwise rotation; $\Delta t$ : output time-step; $T_{\text {shut-down }}$ shutdown trigger time; $\theta_{\text {wave: }}$ wave mean direction with regard to true north; $x=a, b, c, d, e, f$ : six independent seeds for wind and sea state; $T_{\text {sim }}$ : simulation time; $\theta_{\text {wind }}$ : wind mean direction with regard to true north; PM: Pierson-Moskowitz spectrum; and $V_{\text {hub }}$ : mean wind speed at the hub height. 
spectrum of the signal, while the PSD describes how the power of the signal is distributed over frequency.

It should be noted that a direct comparison of the simulated and measured time series was not always possible due to (1) differences in the coordinate systems in which the simulated time series were reported and in which the measurements were recorded and (2) output capabilities of the majority of simulation tools. Therefore, some signal processing was necessary before the data could be compared. The methodology for signals alignment and comparison is described in this section.

Coordinate Systems. All simulation results were delivered by the project participants in terms of time series data. The time series of bending moments, forces, and accelerations were provided in the member local coordinate system, where the member $x_{\text {local }}$-axis is always aligned along the member centerline, $z_{\text {local }}$-axis is perpendicular to the $x_{\text {local }}$-axis and aligned according to the direction cosines for the $z_{\text {local }}$-axis, and $y_{\text {local }}$-axis creates the right-hand Cartesian coordinate system.

All strain and acceleration measurements were provided with regard to the local coordinate systems defined in Ref. [13]. These local coordinate systems are not the same as those used for the simulation results. The alignment of these local coordinate systems was necessary and is described in the following paragraphs.

Wind, wave, and nacelle directions were specified with regard to true north-for both - the measurements and simulations as shown in Fig. 1. Positive values indicate the clockwise direction when looking from the top.

Rotor speed and its azimuth position are defined as positive values when the rotor rotates in the clockwise direction when looking downwind. It is the same convention for the measurements and simulations.

Strain Signals. Strain outputs are not directly available from the majority of the OWT simulation tools. Therefore, it was necessary to derive strain, $\epsilon$, based on the simulated time series of the out-of-plane bending moments, $M_{y}$ local,$M_{z \text { local }}$, axial force, $F_{x \text { local }}$, and geometrical properties of the circular cross section, such as the outer diameter and the wall thickness of the given member.

The relation between the stress, $\sigma$, and the bending moment, $M$, is defined as

$$
\sigma=\frac{M}{I} y
$$

where $I$ is the area moment of inertia for a hollow cylindrical cross section in $\mathrm{m}^{4}$ and $y$ is the distance to the neutral axis in $\mathrm{m}$.

The relation between the stress, $\sigma$, and the strain, $\epsilon$, is described as

$$
\sigma=E \epsilon
$$

where $E$ is Young's modulus in $\mathrm{N} / \mathrm{m}^{2}$.

Combining Eq. (1) with Eq. (2), adding the axial force contribution, and multiplying with $10^{6}$ leads to strain expressed in $\mu \mathrm{m} / \mathrm{m}$ :

$$
\epsilon=\left(\frac{M y}{I E}+\frac{F_{x \text { local }}}{A E}\right) \cdot 10^{6}
$$

where $F_{x \text { local }}$ is the axial force in $\mathrm{N}$ and $A$ is the cross-sectional area of the member in $\mathrm{m}^{2}$.

Furthermore, it was required to align these derived strains with regard to the circumferential positions of the strain gauges installed on the jacket substructure, as described by Eq. (4). An example of a local coordinate system (simulation tool) and a position of the strain gauge (real jacket) is shown for the node kp_2046 in Fig. 3.

$$
M=M_{y \text { local }} \cos (\alpha)+M_{z \text { local }} \sin (\alpha)
$$

where $M_{y}$ local and $M_{z \text { local }}$ are the out-of-plane bending moments in the member local coordinate system, expressed in $\mathrm{Nm}$, and $\alpha$ is the rotation angle to align with the strain gauge position, expressed in deg.
The full-scale strain measurements in the jacket substructure were not calibrated. Therefore, it was necessary to remove the arithmetic mean, $\bar{\epsilon}$, from the measured and computed strain time series, $\epsilon_{i}$, before their comparison:

$$
\epsilon=\epsilon_{i}-\bar{\epsilon}
$$

Some of the measured strain signals had a flipped sign. They were probably installed in the upside-down position. Their sign was corrected during the postprocessing.

Acceleration Signals. The accelerometer data are available at the tower bottom and top in two perpendicular directions in the horizontal plane. The vector magnitude of acceleration was calculated from measured and computed acceleration time series according to the following equation:

$$
|a|=\sqrt{a_{y \text { local }}^{2}+a_{z \text { local }}^{2}}
$$

Other Signals. Other signals, such as electrical power, generator speed, yaw angle, pitch angle, and azimuth angle, are compared directly between the measurements and the simulated data.

\section{Validation Load Cases}

The following operating conditions of the wind turbine were chosen for the validation: (1) idling below the cut-in wind speed; (2) RNA rotation maneuver below the cut-in wind speed; (3) power production below and above the rated wind speed; and (4) power production followed by the shutdown. Seven validation load cases (LCs) were defined based on these operating conditions. Their complexity increases, allowing for the stepwise comparison of results and tracing back possible errors coming from different models and methods implemented in the simulation tools. Table 3 lists all validation LCs that were simulated in Phase III.

The following settings were common for all LCs:

(1) Fully flexible OWT models.

(2) Foundation stiffness was modeled, depending on the individual participant preferences:

(a) By the apparent fixity method, where the OWT piles were fixed at $8.5 \mathrm{~m}$ below the seabed-4S-Simis (ASHES), DTU (HAWC2), EDFRD (DIEGO, FAST V8), Envision (SWT), IFPEN-PR (DeepLW), IWES (MoWiT), NREL (OpenFAST v0.1.0), SWE (Simpack), and UOU (FAST V8).

(b) By applying p-y curves along the foundation piles extending to $42 \mathrm{~m}$ below the seabed-CGC, DNVGL (Bladed V4.8), ClassNK (NK-UTWind), NTNU (SIMA), and UPC (FloaWDyn).

(3) Static blade pitch error of -0.3 deg for blade 2 and +0.3 deg for blade 3-4S-Simis (ASHES), CGC, DNVGL (Bladed V4.8), DTU (HAWC2), EDFRD (DIEGO), Envision (SWT), IFPEN-PR (DeepLW), NREL (OpenFAST v0.1.0), NTNU (SIMA), SWE (Simpack), and UOU (FAST V8).

(4) Static blade mass imbalance for blade 2 by increasing the blade density over the entire blade by $0.6 \%-4 \mathrm{~S}$-Simis (ASHES), CGC, DNVGL (Bladed V4.8), DTU (HAWC2), EDFRD (FAST V8, DIEGO), Envision (SWT), IFPEN-PR (DeepLW), NTNU (SIMA), SWE (Simpack), and UOU (FAST V8).

(5) The jacket substructure rotated $30 \mathrm{deg}$ counterclockwise with regard to true north as shown in Fig. 1.

(6) The jacket substructure legs were flooded up to the mean sea level of $28 \mathrm{~m}$ and the braces were sealed.

(7) Inclination of the mean wind flow with regard to a horizontal plane of 0 deg.

(8) Air density of $1.225 \mathrm{~kg} / \mathrm{m}^{3}$. 
(9) Seawater density of $1025 \mathrm{~kg} / \mathrm{m}^{3}$.

(10) Mean sea level (MSL) of $28 \mathrm{~m}$.

(11) No sea current- the participants did not have access to the sea current measurements. Furthermore, the vast majority of the simulation tools can only model sea current as a deterministic static force, which varies over the depth. The application of the static force profile would not contribute to the analysis of the structural dynamics. Therefore, the negligence of sea current can be justified.

(12) Marine growth applied.

In LC 1.0, the idling turbine below the cut-in wind speed was simulated. This LC was meant to check mean values and signs of the signals from different sensors from the measurements and the simulation results. In LC $1.1 \mathrm{x}$, the idling turbine below the cut-in wind speed was simulated as in LC 1.0. The only difference between these two LCs was introduction of the stochastic sea state instead of the still water. This LC was meant to check the sensitivity of the numerical models to stochastic marine conditions. In LC 1.2, the yaw maneuver of the idling turbine below the cut-in wind speed was simulated.

In LCs $2.1 \mathrm{x}, 2.2 \mathrm{x}$, and $2.3 \mathrm{x}$, the power production was simulated with the stochastic wind files and the stochastic sea state. LCs $2.1 \mathrm{x}$ simulate the power production below rated wind speed, while LCs $2.2 \mathrm{x}$ and $2.3 \mathrm{x}$ simulate the power production above rated wind speed.

In LC 3.1x, the power production above the rated wind speed followed by the normal shutdown was simulated with the stochastic wind files. This LC was meant for analysis of a transient event.

Turbulent wind fields were generated at NREL for LCs 2.Xx and 3.1x. Detailed input parameters for generation of wind fields with Kaimal spectrum by Veers method were specified by Popko [14]. It was decided to use six independent wind seeds $(x=a, b, c, d$, $e, f$ ), each 10-min long, for every single LC in order to get statistically comparable results as recommended in the IEC 61400-1 standard [15]. The stochastic wind files could also be generated individually by those participants whose tools are not able to utilize the provided wind fields because of a different grid format.

For each LC, the outputs were recorded at a number of nodal points denoted as sensors located at the RNA, the tower, and the jacket substructure, as shown in Fig. 2. The location of these outputs corresponds to the location of physical sensors on the actual OWT.

Initial simulation transients were removed by including a presimulation time, $T_{\text {pre }}$, which is simulated but cut-out from the result files in all simulations. For the majority of LCs, $T_{\text {pre }}$ was not explicitly defined. It was chosen individually by each participant in order to avoid initial numerical transients and to satisfy the initial conditions of the given LC. The time-step for data output was defined as $\Delta t=0.05 \mathrm{~s}$ for all LCs.

\section{Selected Results}

This section presents example results of the OWT models validation against the measurements from the Senvion $5 \mathrm{M}$ wind turbine and the jacket support structure from OWEC Tower from the alpha ventus wind farm.

The presented results give a general overview of differences between the measurements and the OC5 Phase III simulation results. The results discussed in this paper represent the final outcome of multiple modeling iterations that were necessary to develop numerical models of the OWT and validation LCs. During each modeling iteration, the participants updated their simulation settings to better match with the measurements.

Rotor-Nacelle Assembly Rotation Maneuver. Figures 4 and 5 show time series of strains with a mean offset adjustment at kp_2036 and kp_307, which are placed at the top of the northern leg and at the lowest X-brace at the northwest jacket side, respectively. The exact locations of these sensors are shown in Fig. 2. The strain signal is changing sinusoidally during the RNA maneuver. The maneuver was simulated in LC 1.2 as described in Table 3.

The measurements are plotted with black curves and are denoted at the bottom of the plot legends as Event_2011-03-23. In both figures. there are some oscillations visible in the measurement signals. Their dominant frequency corresponds to the first global mode of the OWT at around $0.31 \mathrm{~Hz}$. In the case of the measurements recorded at the kp_307 sensor at the lowest X-brace, there is also an additional frequency of around $0.9 \mathrm{~Hz}$. This frequency corresponds to the torsional mode of the support structure. Some irregular peaks appear every $110-180 \mathrm{~s}$ in the measurements from the kp_2036 sensor at the top of the northern leg. They result from the superposition of two frequencies. The first frequency is induced by the yaw mechanism, which rotates the RNA with 2.54 $\mathrm{deg} / \mathrm{s}(0.007 \mathrm{~Hz}$ or $142 \mathrm{~s})$, and the second frequency results from the slowly rotating rotor of the actual wind turbine with around $0.3 \mathrm{rpm}(0.005 \mathrm{~s} \mathrm{~Hz}$ or $200 \mathrm{~s})$. On the contrary to the measurements,

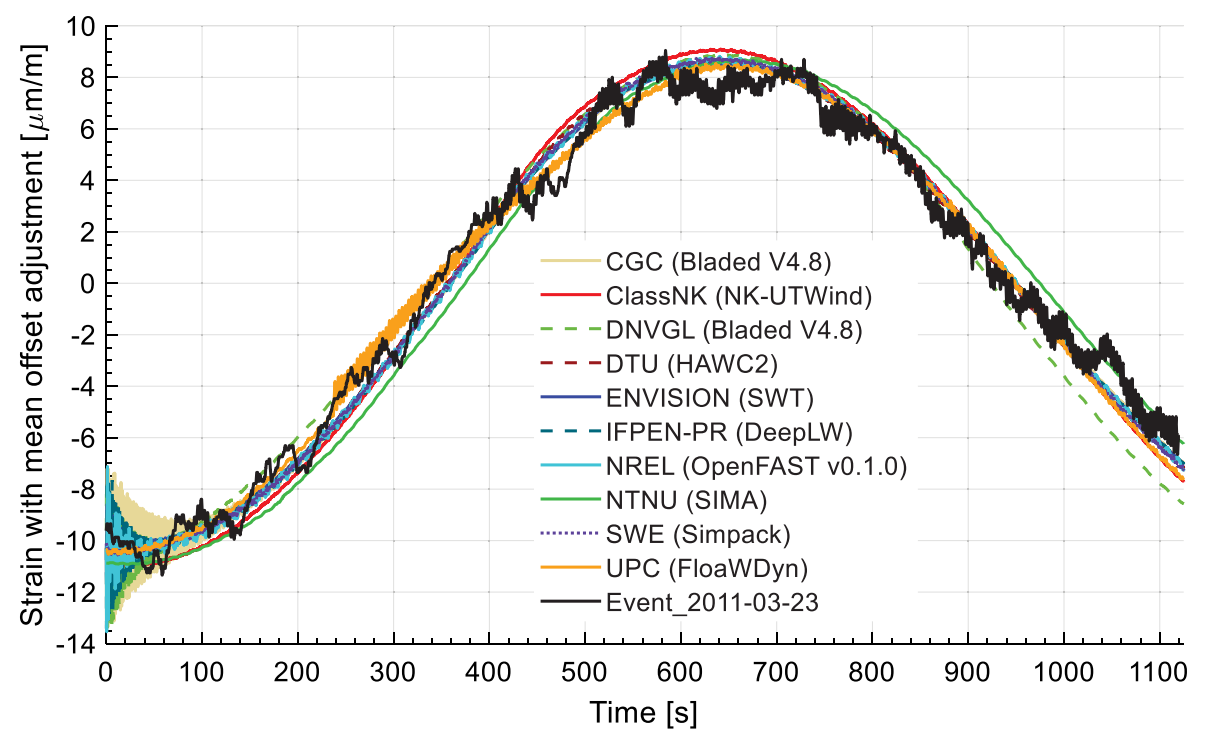

Fig. 4 LC 1.2-strain time series with mean offset adjustment at kp_2036, top of the northern leg 


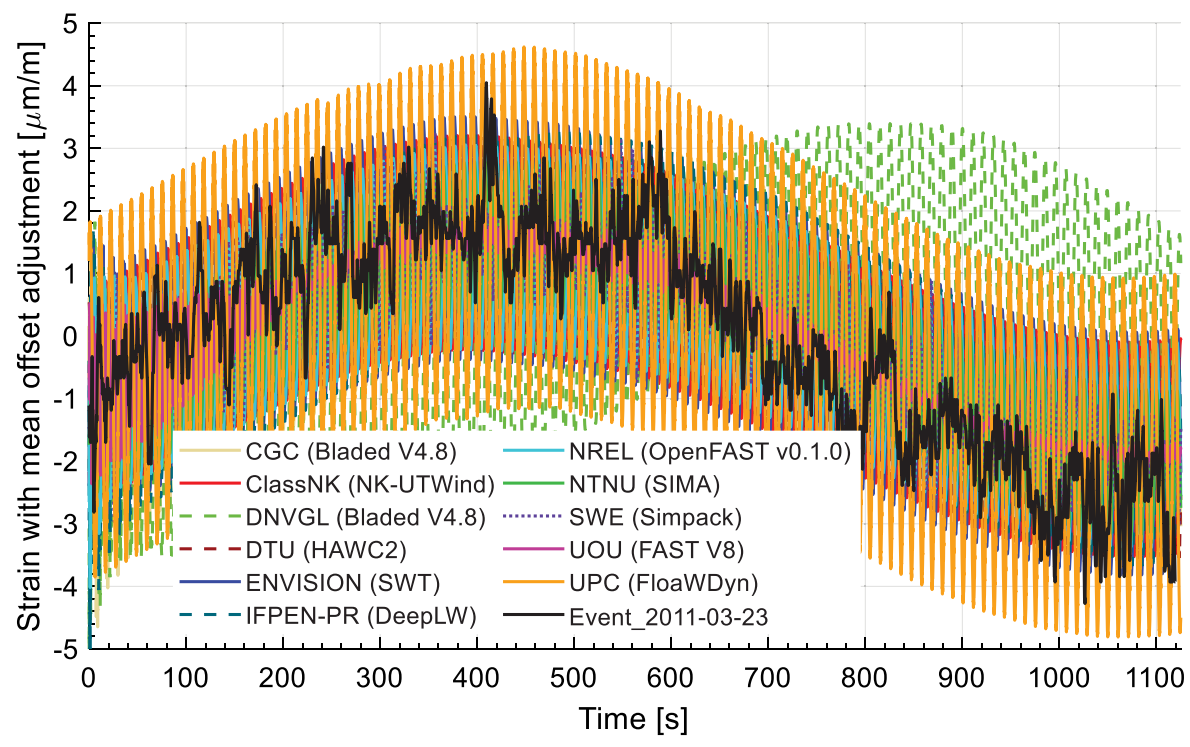

Fig. 5 LC 1.2—strain time series with mean offset adjustment at kp_307, lowest X-brace at northwest jacket side

in the majority of the simulation results the rotor speed was almost zero-it was standing still during the RNA rotation.

In general, the simulation results of the majority of the participants are very well aligned with the measurements. Their amplitudes and phases match the measurement. It should be noted that steady oscillations are present in the majority of the simulation results at the kp_307 sensor (Fig. 5). They are more pronounced than the oscillations visible in the measurements. These oscillations from the simulations are dominated by the tower torsional mode around $0.9 \mathrm{~Hz}$ or the first blade flapwise frequency, which is in the range from $0.58 \mathrm{~Hz}$ to $0.65 \mathrm{~Hz}$. These frequencies were triggered during the simulations due to the sudden start of the yaw maneuver. Project participants did not have access to the yaw mechanism definition, the real turbine controller, and the yaw maneuver initialization procedure. Some transient oscillations are visible in the UOU (FAST V8) results for the kp_307 sensor. However, they could be mitigated by extending the presimulation time. The DNVGL (Bladed V4.8) strain time series at the kp_307 sensor has a flipped sign associated with the incorrect definition of the output coordinate system.

Power Production Above Rated Wind Speed. Figures 6 and 7 show generator power and speed time series for LC 2.2e, respectively. The measurement time series are plotted with different gray shade curves. They come from eight events recorded between April 4 and April 6, 2011, when the met-ocean conditions were relatively comparable. A high variation of the measured generator power, compared with the simulation results, is observed. The standard deviation of generator power varies between $53 \mathrm{~kW}$ and $66 \mathrm{~kW}$ for different measurement events. For the simulation results, the standard deviation is one order of magnitude smaller and varies between 1 and $6 \mathrm{~kW}$. Furthermore, a very significant high-frequency content in the measured generator power, compared to the simulation results, is observed. The PSD analysis proved that the measured generator power has significantly more energy across a wide frequency range. Peaks around $2 \mathrm{~Hz}$ are not really visible in the measured data, but are clearly evident for simulations (not shown in this paper). This indicates that a low-pass filter was used in the actual Senvion controller. On the other hand, the measured generator speed has only a slightly smaller standard deviation compared with the simulation results. For the measurements, it varies within the range of 1.61-2.62 $\mathrm{rpm}$, whereas for the simulations it varies from $2.59 \mathrm{rpm}$ to 3.28 rpm. It can be concluded that the actual Senvion controller acts more aggressively on the generator torque to keep the generator speed constant.

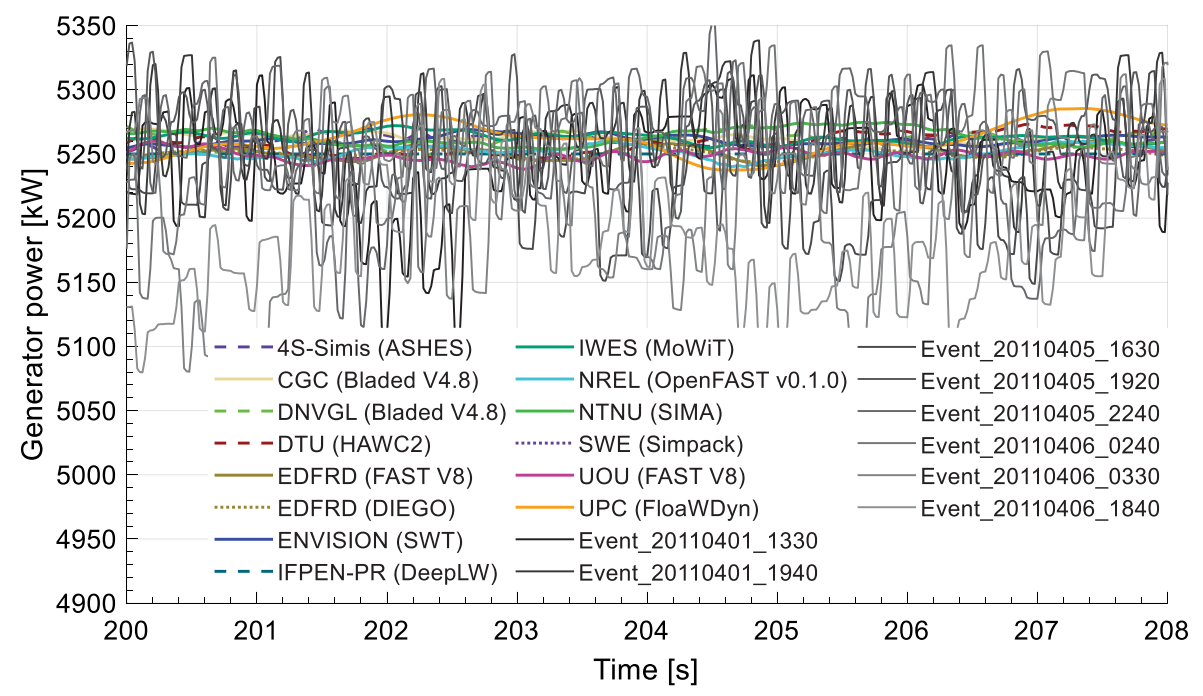

Fig. 6 LC 2.2e-zoomed generator power time series 


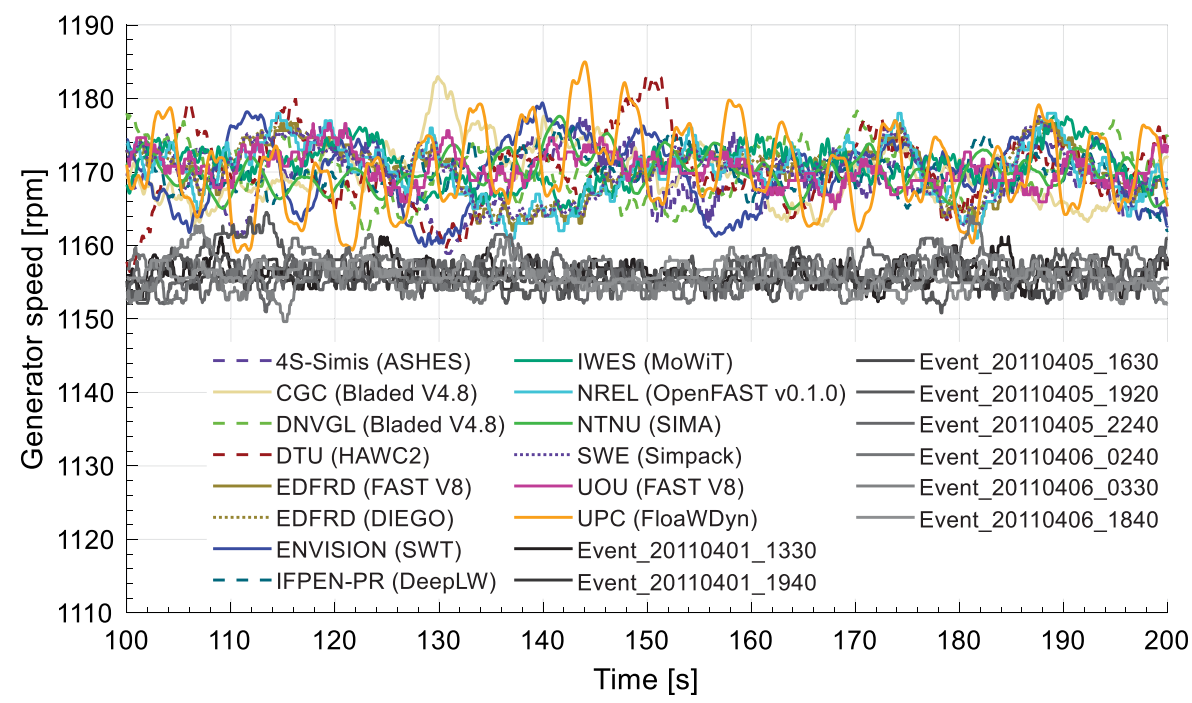

Fig. 7 LC 2.2e-zoomed generator speed time series

It should be mentioned that a similar, aggressive torque control was also observed in the partial loading region in the measurements for LC 2.1.

Figures 8 and 9 show single-sided amplitude spectra from DFT of aggregated strain time series of six simulation seeds from LC 2.2 at kp_2026 (eastern leg top) and kp_2021 (eastern leg bottom), respectively. The exact locations of these sensors are shown in Fig. 2. Vertical dotted lines in both DFT figures indicate subsequent rotor harmonics $(1 \mathrm{P}, 3 \mathrm{P}, 6 \mathrm{P}$, and $9 \mathrm{P})$ above the rated wind speed, $V_{\mathrm{r}}$, and global eigenmodes that are also described with the vertical text. These dotted lines help to identify sources of frequency peaks.

The strain amplitude at the frequency corresponding to $1 \mathrm{P}$ $(0.2 \mathrm{~Hz})$ is significantly underpredicted by IWES (MoWiT) for both sensors-higher (kp_2026) and lower (kp_2021) location at the eastern leg. IWES did not use the blade mass imbalance and the static pitch error in its OWT model. On the other hand, a strong overprediction of the $1 \mathrm{P}(0.2 \mathrm{~Hz})$ frequency is observed in case of NTNU (SIMA). This might partially be caused by the modeling approach utilized by NTNU-the mass imbalance was modeled in SIMA by adding an extra beam element parallel to one blade. This beam had $0.6 \%$ of the mass of the original blade, and its stiffness was reduced accordingly. The nodes at each end of the beam were slaved to the blade root and blade tip, and no loads were applied to this beam.

The strain amplitude at the frequency corresponding to the first global mode $(0.31 \mathrm{~Hz})$ is significantly underpredicted by simulations for both sensors-higher (kp_2026) and lower (kp_2021) location at the eastern leg. The strain amplitude at the frequency dominated by 3P and the first flapwise mode (both around $0.6 \mathrm{~Hz}$ ) is relatively well captured in the simulation results for both locations. The amplitudes at higher frequencies at around $1.8-1.9 \mathrm{~Hz}$ are significantly overpredicted by simulations at kp_2021 at the bottom of the leg. This is not observed for kp_2026 at the top of the leg. There is a significant increase of amplitudes for the measurements at the frequencies above $2 \mathrm{~Hz}$ at kp_2021 at the bottom of the leg. This is not observed in the simulation results. All these observations also apply to LC 2.3 .

In summary, the underprediction of amplitudes at the lower frequencies (up to $0.4 \mathrm{~Hz}$ ) would indicate issues with the system damping. The damping values used in the numerical models

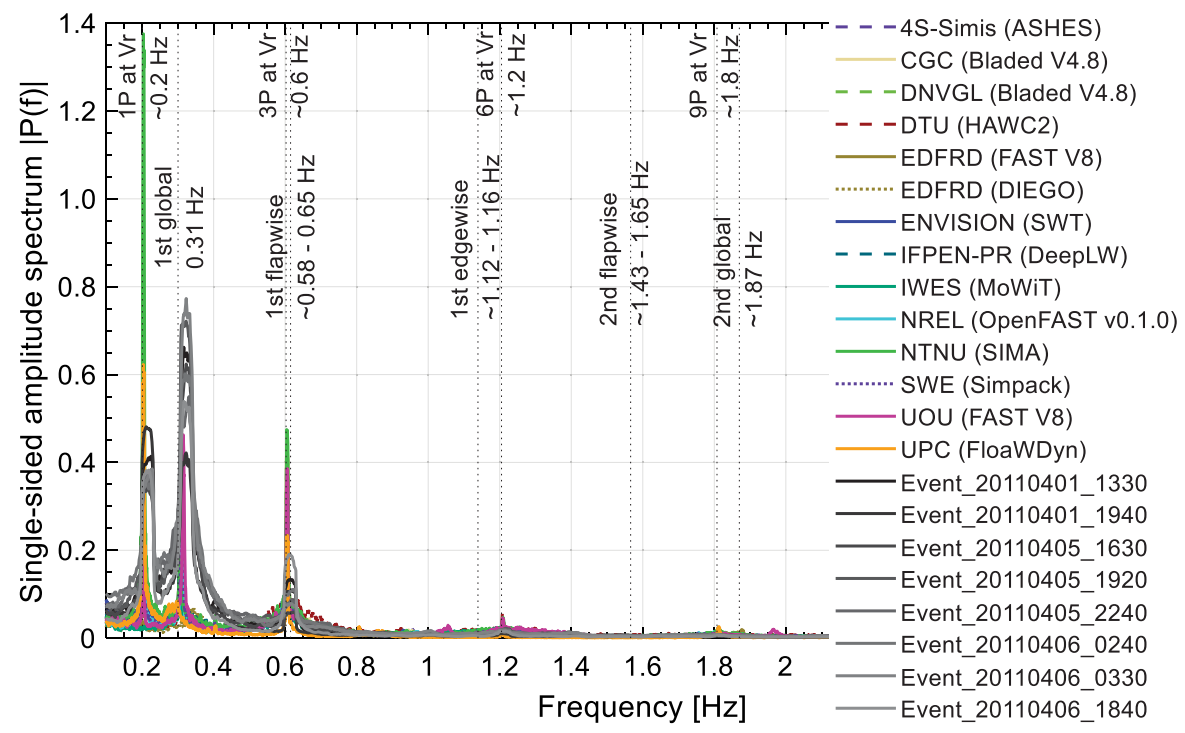

Fig. 8 LC 2.2-single-sided amplitude spectrum from DFT of aggregated strain time series of six seeds at kp_2026, Eastern leg top 


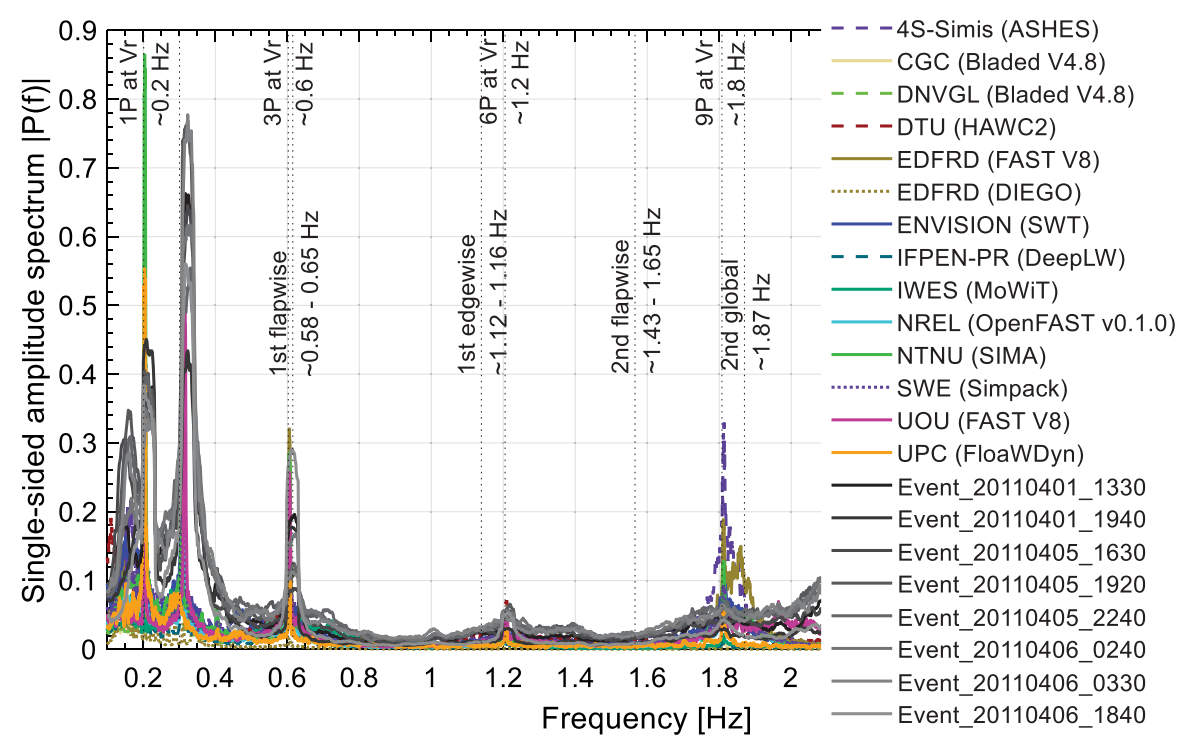

Fig. 9 LC 2.2-single-sided amplitude spectrum from DFT of aggregated strain time series of six seeds at kp_2021, Eastern leg bottom

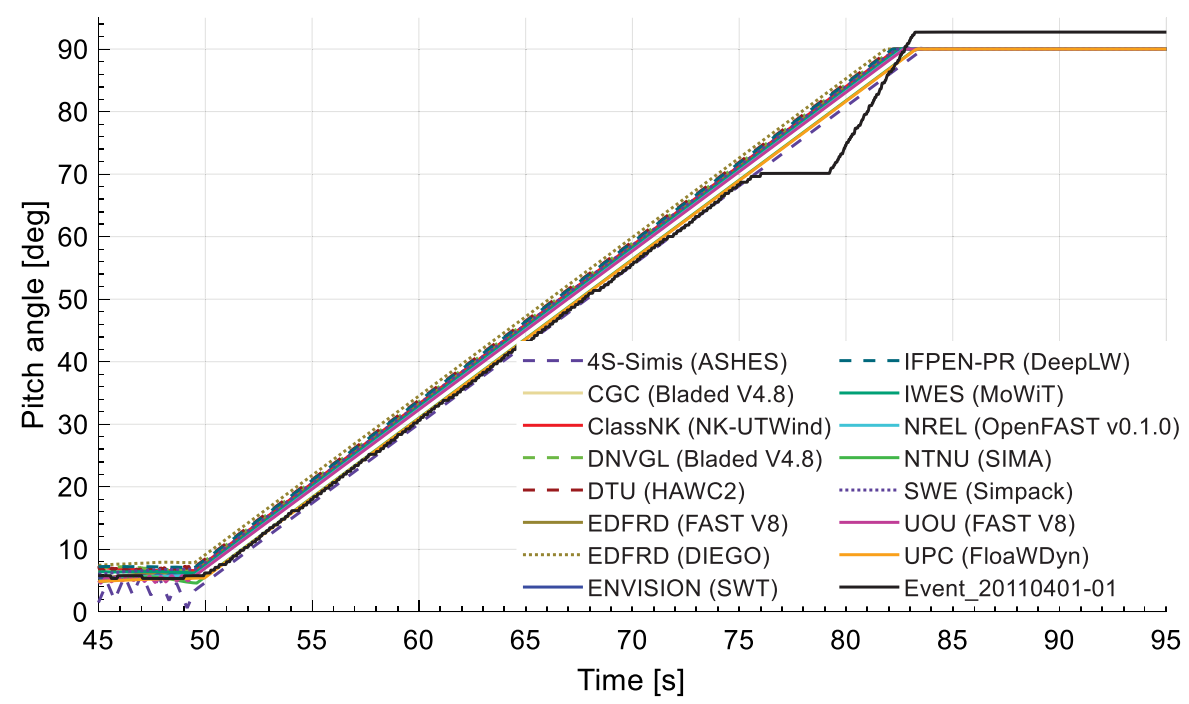

Fig. 10 LC 3.1f-pitch angle time series

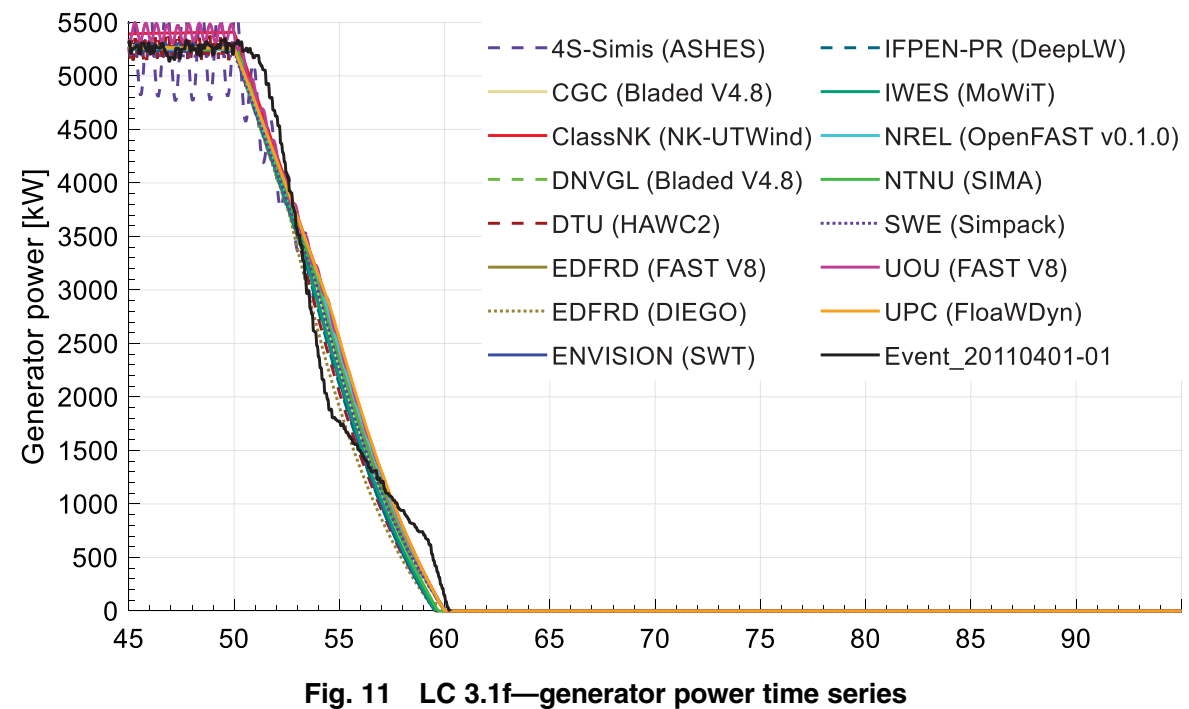




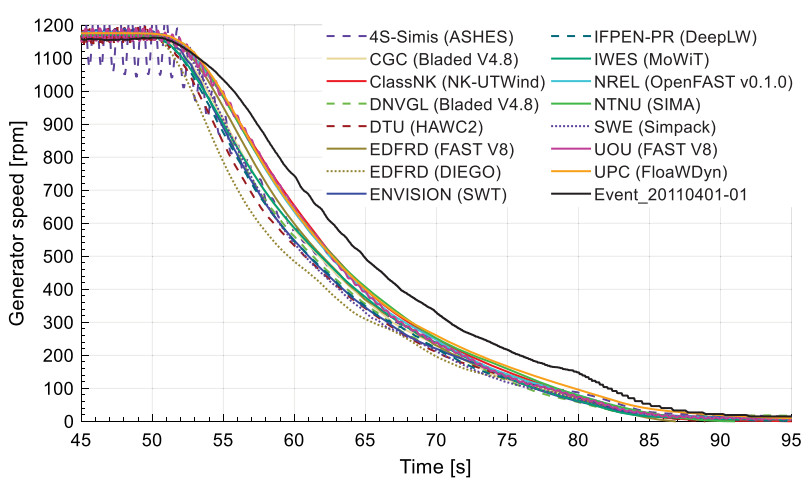

Fig. 12 LC 3.1f-generator speed time series

might be too high. The estimation of an appropriate damping value for the structure is difficult. The damping issue seems to be the biggest limitation identified in the tools, which should be more directly investigated in the future. The overprediction of simulated strain amplitudes at higher frequencies at around $1.9 \mathrm{~Hz}$ might be related to filters used in the controller.
Shutdown Transient Event. The power production followed by the normal shutdown was simulated according to LC $3.1 \mathrm{x}$ defined in Table 3. This LC was meant for the analysis of the transient behavior of the OWT. The measurements are always plotted with black curves and denoted at the bottom of the plot legends as Event_20110401-01.

Figure 10 shows the time series of the pitch angle during the normal operation of the OWT just before the shutdown was triggered (45-50s), during the shutdown (50-83 s), and just after (83-95 s). For the majority of the simulation results, the mean pitch angle is slightly larger than the measured one during the power production $(45-50 \mathrm{~s})$. This is caused by differences in blade aerodynamics between the tuned NREL 5-MW blades(utilized in OC5 Phase III) and the real Senvion 5M turbine, as explained by Popko [7]. The measured pitch angle during the shutdown increases linearly to $70 \mathrm{deg}$ from $50 \mathrm{~s}$ up to $76 \mathrm{~s}$; afterward, it is kept constant for around $4 \mathrm{~s}$, then continues pitching to feather with a slightly higher rate. The reason for this intermediate stop in pitching in the measured signal is unknown. For the simulations, it was decided to use the constant pitch action from $50 \mathrm{~s}$ to $83 \mathrm{~s}$ until all blades are pitched to $90 \mathrm{deg}$. This is a reasonable simplification.

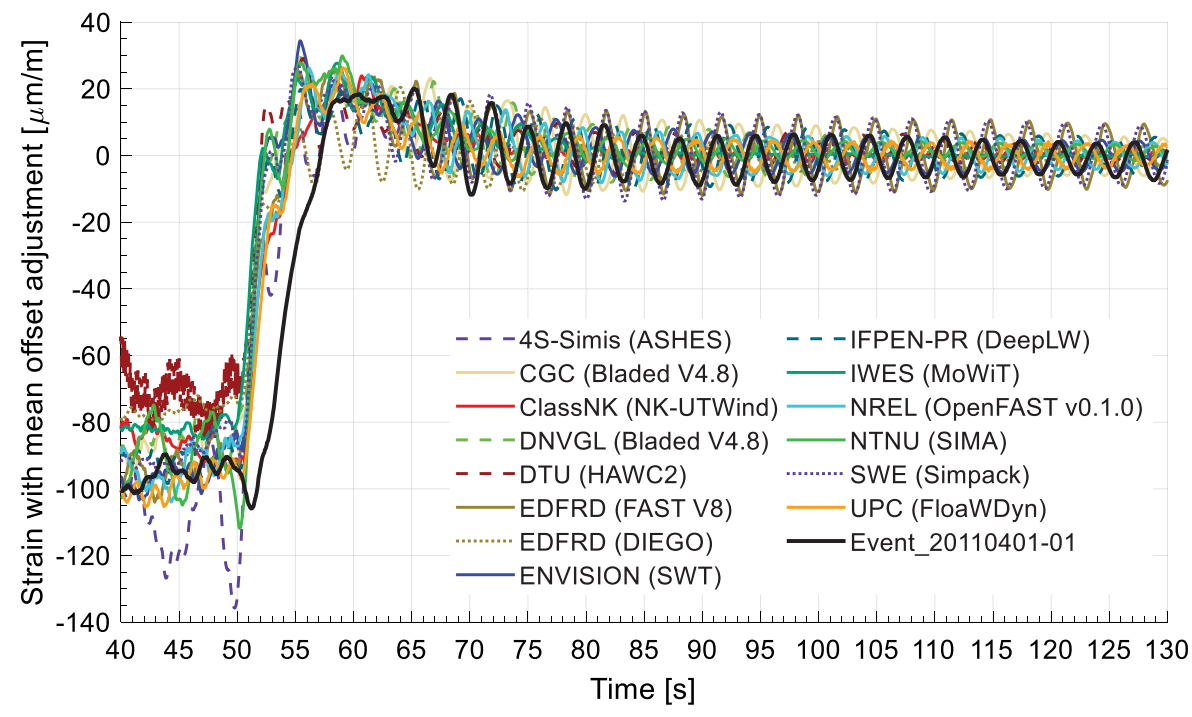

Fig. 13 LC 3.1F-strain time series with mean offset adjustment at kp_2026, top of the eastern leg

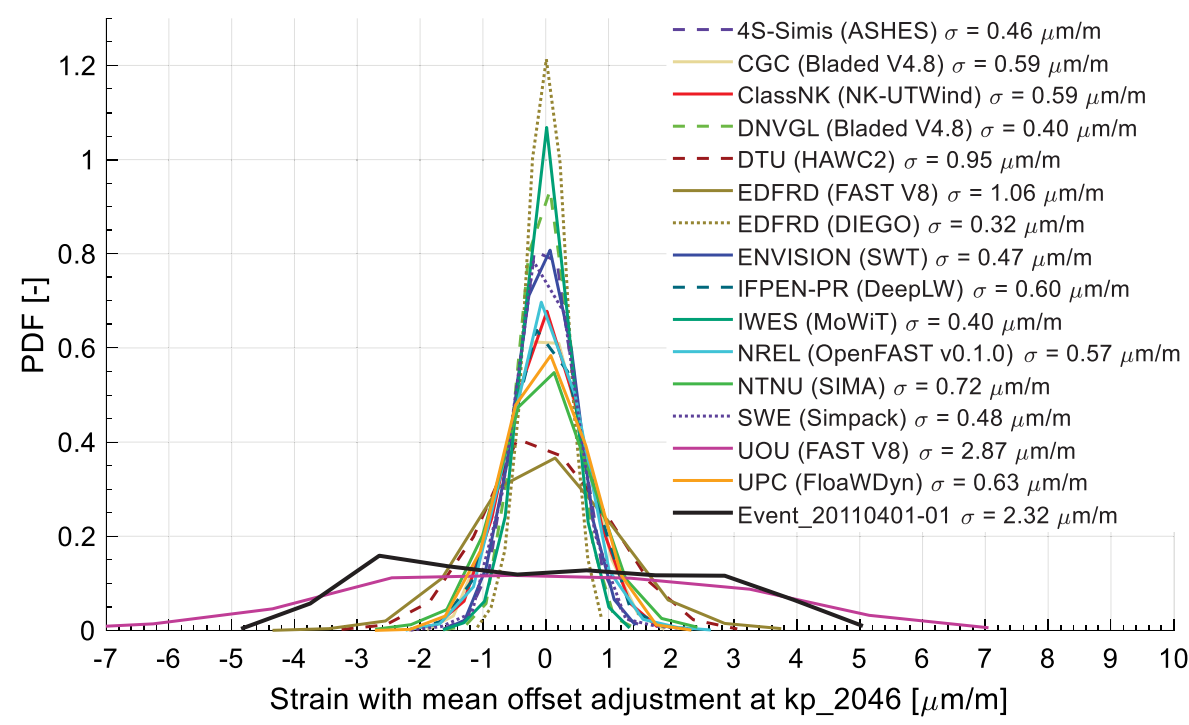

Fig. 14 LC 3.1-PDF of aggregated strain time series of six seeds at kp_2046 at the top of western leg, calculated from the last $300 \mathrm{~s}$ of simulation 


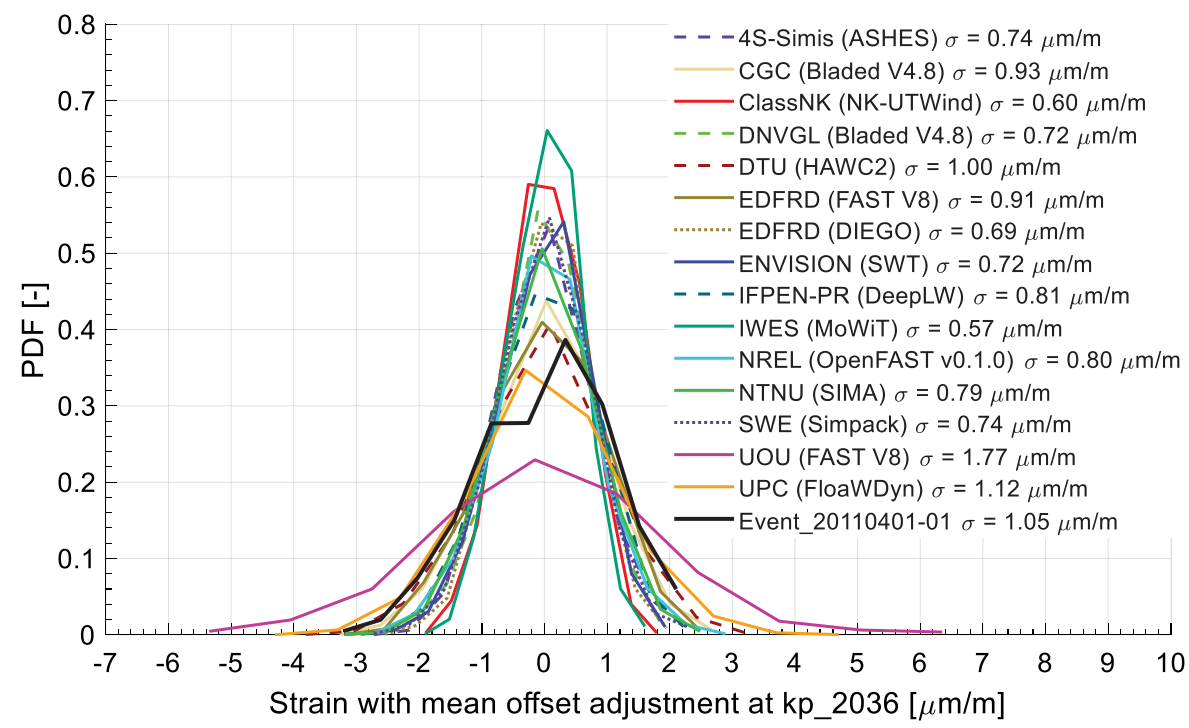

Fig. 15 LC 3.1-PDF of aggregated strain time series of six seeds at kp_2036 at the top of northern leg, calculated from the last $300 \mathrm{~s}$ of simulation

Figure 11 shows the generator power time series. The majority of the simulation results follow the measurement. The measured generator power drops nonlinearly from its rated value to $0 \mathrm{Nm}$ within $10 \mathrm{~s}$. For the simulation of OWT models, it was decided to implement a simplified linear drop of the generator torque. This simplification can be justified because it should not have a large impact on the loads in the jacket substructure.

Figure 12 shows the generator speed time series. The measured speed is always kept higher during the shutdown event when compared with the simulation results. This is caused by differences in blade aerodynamics between the tuned NREL 5-MW blades (utilized in OC5 Phase III) and the real Senvion 5M turbine, and the control system.

Figure 13 shows the time series of strain with mean offset adjustment during the shutdown event at the kp_2026 sensor located at the top of the eastern leg (Fig. 2). Note that the measurement signal has a smaller overshoot at around $60 \mathrm{~s}$ when compared with the majority of the simulation results. The real turbine controller is able to efficiently mitigate loads resulting from the shutdown.
Figures 14-17 show PDFs of strain at the western (kp_2046), northern (kp_2036), eastern (kp_2026), and the southern (kp_2011) leg, respectively. All PDFs were calculated based on the last $300 \mathrm{~s}$ of the $600 \mathrm{~s}$ time series. This was done to analyze damping of the entire OWT. Standard deviations for all signals are shown in the legends. The critical damping values used in the numerical models are presented in Table 4.

Please note that the appropriate damping setting depends on how the damping is applied (modal versus stiffness/mass proportional as defined in Table 4) and how the mode is defined (fixed-fixed versus fixed-free). For example, in FAST a percentage of critical damping can be specified for the tower modes as well as for the jacket modes that are derived through the Craig-Bampton $(\mathrm{CB})$ reduction. Fixed-bottom substructures in FAST are modeled in the SubDyn module, which assumes a fixed-boundary condition at the top and the bottom of the jacket for the $\mathrm{CB}$ modal reduction. Therefore, the structural damping defined for the $\mathrm{CB}$ reduction only affects jacket internal modes and has little effect on global bending modes of the entire system that involve displacement of the TP. On the other

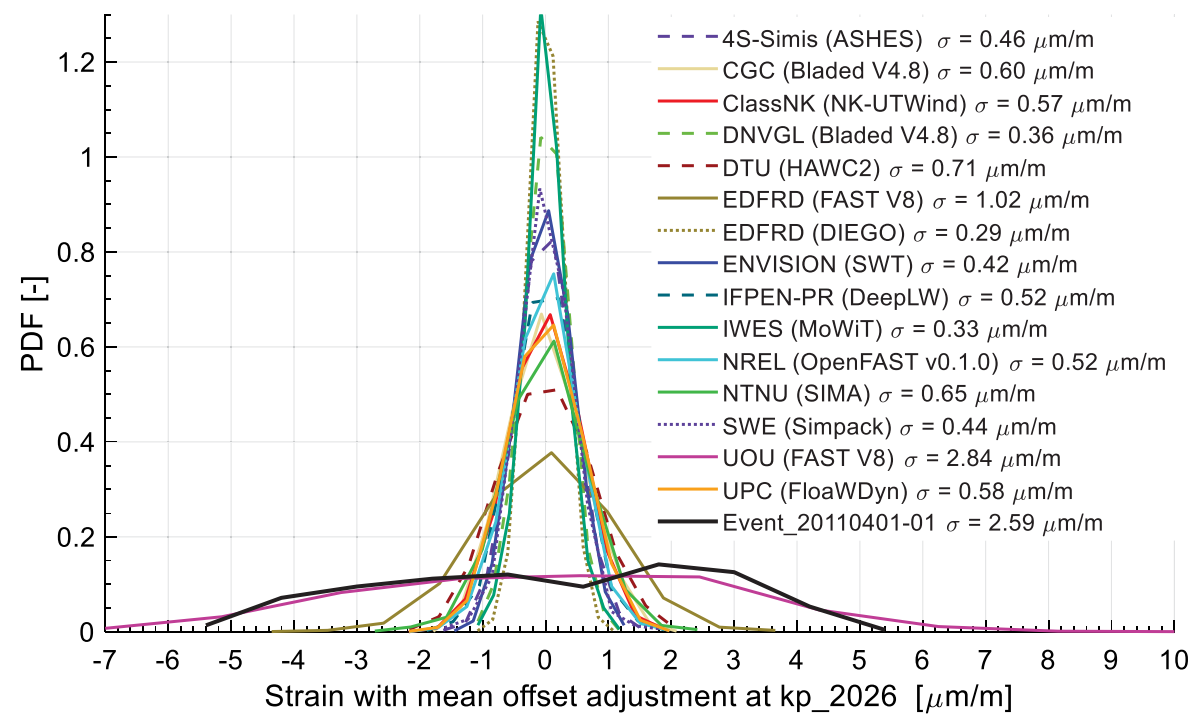

Fig. 16 LC 3.1-PDF of aggregated strain time series of six seeds at kp_2026 at the top of eastern leg, calculated from the last $300 \mathrm{~s}$ of simulation 


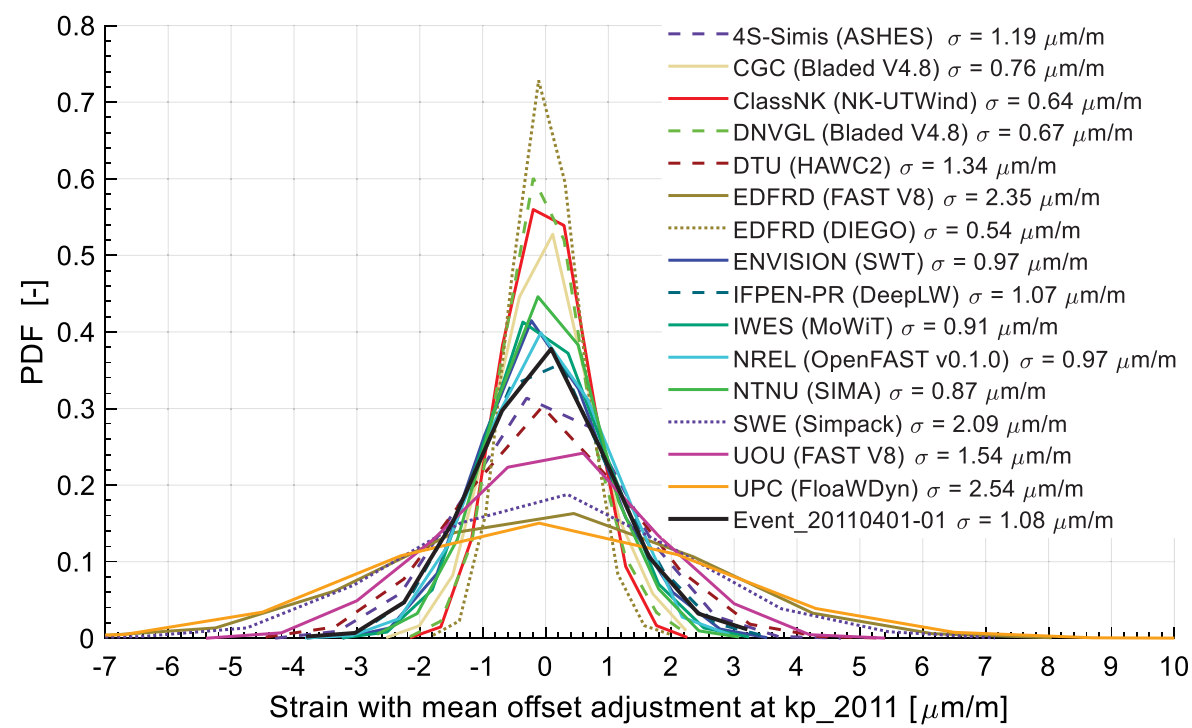

Fig. 17 LC 3.1-PDF of aggregated strain time series of six seeds at kp_2011 at the bottom of southern leg, calculated from the last $300 \mathrm{~s}$ of simulation

Table 4 Percentage of critical damping ratio for main OWT components modeled by different Phase III participants

\begin{tabular}{|c|c|c|c|c|c|c|}
\hline Participant & Tool & $\begin{array}{l}\text { Jacket }+ \\
\text { piles }\end{array}$ & Tower & Blades & Drivetrain & Comments \\
\hline UPC & FloaWDyn & $0.16 \%$ & $0.40 \%$ & $\begin{array}{l}\text { no } \\
\text { damping }\end{array}$ & rigid & $\begin{array}{l}\text { Support structure: Stiffness and mass proportional Rayleigh, }{ }^{\text {a }} \\
\text { Blade: No damping }\end{array}$ \\
\hline IWES & MoWiT & $0.16 \%$ & $1.24 \%$ & $2 \%$ & $5 \%$ (torsional) & $\begin{array}{l}\text { Support structure: Stiffness and mass proportional Rayleigh, } \\
\text { Blade: Modal (eight modes) }\end{array}$ \\
\hline Envision & SWT & $0.16 \%$ & $0.40 \%$ & $0.48 \%$ & $\begin{array}{l}4.77 \% \\
\text { (torsional) }\end{array}$ & Support structure: Stiffness proportional Rayleigh, Blade: Modal \\
\hline NTNU & SIMA & $0.16 \%$ & $0.40 \%$ & $0.23 \%$ & rigid & Support structure and blade: Stiffness proportional Rayleigh ${ }^{\mathrm{c}}$ \\
\hline 4S-Simis & ASHES & $0.16 \%$ & $0.40 \%$ & $\begin{array}{l}\text { no } \\
\text { damping }\end{array}$ & $\begin{array}{l}\text { flexible, no } \\
\text { damping }\end{array}$ & $\begin{array}{l}\text { Support structure: Stiffness proportional Rayleigh, Blade: No } \\
\text { damping }\end{array}$ \\
\hline ClassNK & NK-UTWind & $1.24 \%$ & $1.24 \%$ & $0.48 \%$ & rigid & $\begin{array}{l}\text { Support structure: Stiffness proportional Rayleigh, Blade: Modal } \\
\text { (three modes) }\end{array}$ \\
\hline DTU & HAWC2 & $0.70 \%$ & $0.40 \%$ & $0.48 \%$ & rigid & Support structure and blade: Stiffness proportional Rayleigh \\
\hline IFPEN-PR & DeepLW & $\begin{array}{l}\text { no } \\
\text { damping }\end{array}$ & $0.40 \%$ & $0.48 \%$ & rigid & Tower and blade: Stiffness proportional Rayleigh \\
\hline CGC & Bladed V4.8 & $0.50 \%$ & $0.50 \%$ & $0.48 \%$ & $\begin{array}{l}4.77 \% \\
\text { (torsional) }\end{array}$ & $\begin{array}{l}\text { Support structure and blade: Modal (16 support structure modes, } \\
\text { seven blade modes) }\end{array}$ \\
\hline DNVGL & Bladed V4.8 & $1.24 \%$ & $1.24 \%$ & $0.26 \%$ & flexible & Support structure and blade: Modal (six blade modes) \\
\hline NREL & OpenFAST & $1 \%$ & $0.80 \%$ & $0.48 \%$ & flexible & $\begin{array}{l}\text { Support structure and blade: Modal (eight jacket modes, four } \\
\text { tower modes, three blade modes) }\end{array}$ \\
\hline UOU & FAST V8 & $1 \%$ & $0.40 \%$ & $0.48 \%$ & rigid & $\begin{array}{l}\text { Support structure and blade: Modal (eight jacket modes, four } \\
\text { tower modes, three blade modes) }\end{array}$ \\
\hline EDFRD & FAST V8 & $0.16 \%$ & $1.24 \%$ & $0.48 \%$ & rigid & $\begin{array}{l}\text { Support structure and blade: Modal (four tower modes, three } \\
\text { blade modes) }\end{array}$ \\
\hline EDFRD & DIEGO & $1.24 \%$ & $1.24 \%$ & $0.48 \%$ & rigid & $\begin{array}{l}\text { Support structure and blade: Stiffness and mass proportional } \\
\text { Rayleigh }\end{array}$ \\
\hline SWE & Simpack & $1 \%$ & $0.40 \%$ & $0.48 \%$ & rigid & $\begin{array}{l}\text { Support structure and blade: Modal (eight jacket modes, four } \\
\text { tower modes, three blade modes) }\end{array}$ \\
\hline
\end{tabular}

${ }^{a}$ In FloaWDyn model, an equivalent Rayleigh method is applied in the corotational element axes. The damping matrix applied is a linear combination of the mass and stiffness matrices acting over the corotational local deformation velocity.

${ }^{\mathrm{b}}$ In SWT. a percentage of critical damping can be specified for the blade modes that are derived through a Craig-Bampton $(\mathrm{CB})$ reduction. The modal base for the blade is characterized based on a fixed-free boundary condition. This modally reduced blade (that contains the damping) is linked node by node to a nonreduced blade defined by means of nonlinear beams (that contain the structural properties). Through this approach, it is possible to superpose a modal damping to a nonlinear beam able to capture the blade deflections accurately.

'In SIMA, the damping is specified as Rayleigh proportional damping. This can be applied as both mass and stiffness proportional damping, but only stiffness proportional damping is used within the simulations in this paper. Separate damping coefficients can be specified for all structural elements. Here, damping coefficients have been set to give the damping levels in Table 4 at the frequency of the first global mode for the jacket and tower. For the blades, the damping is set to the specified level for the frequency corresponding to the first asymmetric flapwise yaw mode. For frequencies below those specified here, the damping level will be lower than provided in Table 4. Correspondingly, the damping will be larger for the higher frequencies. 
hand, the damping in NK-UTWind, DIEGO (Rayleigh damping), and Bladed (modal damping) is actually applied to the entire support structure (jointly to the tower and the substructure)-it is not split as in FAST. In other tools, this might be done differently; therefore, it is difficult to directly compare damping values used in different simulation tools.

A relatively good agreement between the measurements and the simulation results is observed at the northern and southern legsthe standard deviation of the measurement is only slightly larger than the standard deviations for the majority of simulation results. This would imply that the soil and structural damping values, which were used in the OWT models, were tuned correctly. Much larger oscillations of measurements are observed at the western and eastern legs. In this case, the standard deviation of the measurements is around four times larger than the standard deviations of simulated signals. This behavior might be attributed to the actual soil properties because a similar directional phenomenon was also observed in the measurement of the idling turbine in LCs 1.0 and 1.1x.

\section{Conclusions}

Validation of the OWT numerical models against the full-scale open-ocean system was a particularly challenging task. The participants of OC5 Phase III did not have access to the real blade design data and the full wind turbine controller due to confidentiality-it should not be forgotten that the load effects are sensitive to the controller and airfoil properties, which were only approximated in the modeling approach. Also, large measurement uncertainties related to the open-ocean environment created additional challenges when setting up the validation LCs. There was also the need for a thorough quality check of sensor measurements because inconsistencies were seen for those that had been originally identified as accurate by RAVE.

Nevertheless, the obtained results are satisfactory and show that the numerical models can reasonably mimic the full-scale system when they are carefully tuned.

In Phase III, the following objectives of the OC5 project were fulfilled:

(1) Identifying and validating the capabilities and limitations of implemented theories.

The damping issue seems to be the biggest limitation identified in the tools that should be more directly investigated in the future to improve the engineering modeling approach and understanding. The estimation of an appropriate damping value for the structure turned out to be an issue. First of all, the originally provided values seemed to be too high. Second, different tools utilize different damping models for different turbine components, which made the damping tuning even more challenging.

(2) Training new analysts how to run and apply the tools correctly.

A lot of time was spent on multiple iterations of results. During each modeling iteration, the participants updated their OWT models to better match with the measurements.

(3) Identifying further research and development needs.

The experience gained from validating small- and fullscale systems in the OC5 project will lead to a more rigorous validation practice, which will be developed and employed in the follow-up project called Offshore Code Comparison Collaboration, Continued, with Correlation, and unCertainty (OC6). The new project will have a strong emphasis on quantifying uncertainty in test campaigns used for validation.

\section{Acknowledgment}

OWEC Tower is acknowledged for releasing the jacket substructure, transition piece, and foundation design data for Phase III.
Senvion is acknowledged for sharing the definition of the Senvion 5M wind turbine and its tower.

The RAVE consortium is acknowledged for releasing the measurement data from the alpha ventus wind farm.

This work was authored (in part) by the National Renewable Energy Laboratory, operated by Alliance for Sustainable Energy, LLC, for the U.S. Department of Energy (DOE) under Contract No. DE-AC36-08GO28308. Funding provided by the U.S. Department of Energy Office of Energy Efficiency and Renewable Energy Wind Energy Technologies Office. The views expressed in the article do not necessarily represent the views of the DOE or the U.S. Government.

The submitted manuscript has been created by UChicago Argonne, LLC, Operator of Argonne National Laboratory ("Argonne"). Argonne, a U.S. Department of Energy Office of Science laboratory, is operated under Contract No. DE-AC0206CH11357. The Department of Energy will provide public access to these results of federally sponsored research in accordance with the DOE Public Access Plan. http://energy.gov/downloads/ doe-public-accessplan

\section{Conflict of Interest}

There are no conflicts of interest.

\section{References}

[1] Musial, W., Robertson, A., Jonkman, J., Vorpahl, F., and Popko, W., 2013, "Annex 30 - Task Extension Proposal, 2014-2017 Offshore Code Comparison Collaboration Continuation (OC4)," International Energy Agency, Technical Report, September.

[2] Jonkman, J., and Musial, W., 2010, "IEA Wind Task 23 Offshore Wind Technology and Deployment," National Renewable Energy Laboratory, Golden, CO, December, Technical Report No. NREL/TP-5000-48191, https:// www.nrel.gov/docs/fy11osti/48191.pdf

[3] Robertson, A., Jonkman, J., Musial, W., Popko, W., and Vorpahl, F., 2014, "Final Technical Report - IEA Wind Task 30 Offshore Code Comparison Collaboration Continued," The International Energy Agency Wind, April, Technical Report, http://www.ieawind.org/index_page_postings/task30/Task30_Final_Technical_ Report.pdf

[4] Robertson, A. N., Wendt, F., Jonkman, J. M., Popko, W., Borg, M., Bredmose, H., Schlutter, F., Qvist, J., Bergua, R., Harries, R., Yde, A., Nygaard, T. A., de Vaal, J. B., Oggiano, L., Bozonnet, P., Bouy, L., Sanchez, C. B., García, R. G., Bachynski, E. E., Tu, Y., Bayati, I., Borisade, F., Shin, H., van der Zee, T., and Guerinel, M., 2016, "OC5 Project Phase Ib: Validation of Hydrodynamic Loading on a Fixed, Flexible Cylinder for Offshore Wind Applications," Energy Procedia, 94(Sept.), pp. 82-101.

[5] Robertson, A. N., Wendt, F., Jonkman, J. M., Popko, W., Dagher, H., Gueydon, S., Qvist, J., Vittori, F., Azcona, J., Uzunoglu, E., Soares, C. G., Harries, R., Yde, A., Galinos, C., Hermans, K., de Vaal, J. B., Bozonnet, P., Bouy, L., Bayati, I., Bergua, R., Galván, J., Mendikoa, I., Sanchez, C. B., Shin, H., Oh, S., Molins, C., and Debruyne, Y., 2017, "OC5 Project Phase II: Validation of Global Loads of the DeepCwind Floating Semisubmersible Wind Turbine," Energy Procedia, 137(October), pp. 38-57.

[6] Wikipedia, 2009, "Lage und Detailkarte des Windparks Alpha Ventus in der Nordsee [in German]," January, https://de.wikipedia.org/wiki/Alpha_ventus\#/ media/File:Windpark_alpha_ventus_Lagekarte.png

[7] Popko, W., Huhn, M. L., Robertson, A., Jonkman, J., Wendt, F., Müller, K., Kretschmer, M., Vorpahl, F., Hagen, T. R., Galinos, C., Le Dreff, J.-B., Gilbert, P., Auriac, B., Víllora, F. N., Schünemann, P., Bayati, I., Belloli, M., Oh, S., Totsuka, Y., Qvist, J., Bachynski, E., Sørum, S. H., Thomassen, P. E., Shin, H., Vittori, F., Galván, J., Molins, C., Bonnet, P., van der Zee, T., Bergua, R., Wang, K., Fu, P., and Cai, J., 2018, "Verification of a Numerical Model of the Offshore Wind Turbine From the Alpha Ventus Wind Farm Within OC5 Phase III," Proceedings of the ASME 2018 37th International Conference on Ocean, Offshore and Arctic Engineering OMAE 2018, Madrid, June.

[8] Popko, W., 2017, "OC5 Phase III - RNA and Tower Definition [Confidential]," Fraunhofer Institute for Wind Energy Systems IWES, Bremerhaven, December, Technical Report.

[9] Kaufer, D., and Cheng, P. W., 2014, "Validation of an Integrated Simulation Method with High Resolution Load Measurements of the Offshore Wind Turbine REpower 5M at Alpha Ventus,” J. Ocean Wind Energy, 1(1), pp. 3040, http://www.isope.org/publications/jowe/jowe-01-1/JOWE-01-1-p030-arr01Kaufer.pdf

[10] Müller, K., Reiber, M., and Cheng, P., 2016, "Comparison of Measured and Simulated Structural Loads of an Offshore Wind Turbine at Alpha Ventus," 
Int. J. Offshore Polar Eng., 26(3), pp. 209-218, https://www.onepetro.org/journalpaper/ISOPE-16-26-3-209

[11] Fraunhofer IWES, 2017. OWEA Loads - Probabilistic Load Description, Monitoring and Reduction of Loads of Future Offshore Wind Turbines, http:// www.rave-offshore.de/en/owea-loads.html

[12] IEC, 2009, "IEC 61400-3 Wind Turbines - Part 3: Design Requirements for Offshore Wind Turbines," International Electrotechnical Commission, Geneva, February.
[13] GL Garrad Hassan, 2012, "RAVE - Sensor Description AV 04," Version Fraunhofer IWES, Bremerhaven, Projekt: GIGAWINDav (in German), GL Garrad Hassan, Technical Report.

[14] Popko, W., 2017, "OC5 Phase III-Verification of OWT Model [Confidential]," Fraunhofer Institute for Wind Energy Systems IWES, Bremerhaven, December, Technical Report.

[15] IEC, 2005, "IEC 61400-1 Wind Turbines - Part 1: Design Requirements, 3rd ed., International Electrotechnical Commission, Geneva, August. 